Portland State University

PDXScholar

\title{
A study of the photolysis of 0-methyl podocarpinitrile oxide
}

Dianne Marie Hunter

Portland State University

Follow this and additional works at: https://pdxscholar.library.pdx.edu/open_access_etds

Part of the Organic Chemistry Commons

Let us know how access to this document benefits you.

\section{Recommended Citation}

Hunter, Dianne Marie, "A study of the photolysis of O-methyl podocarpinitrile oxide" (1980). Dissertations and Theses. Paper 2962.

https://doi.org/10.15760/etd.2958

This Thesis is brought to you for free and open access. It has been accepted for inclusion in Dissertations and Theses by an authorized administrator of PDXScholar. Please contact us if we can make this document more accessible: pdxscholar@pdx.edu. 
AN ABSTRACT OF THE THESIS OF Dianne Marie Hunter, for the Master of Science in Chemistry, presented February 22, 1980.

Title: A Study of the Photolysis of O-Methyl Podocarpinitrile Oxide APPROVED BY MEMBERS OF THE THESIS COMMITTEE:

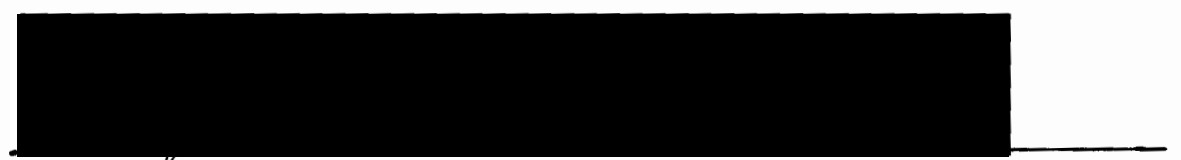

Alfred/S. Levinson, Chairman
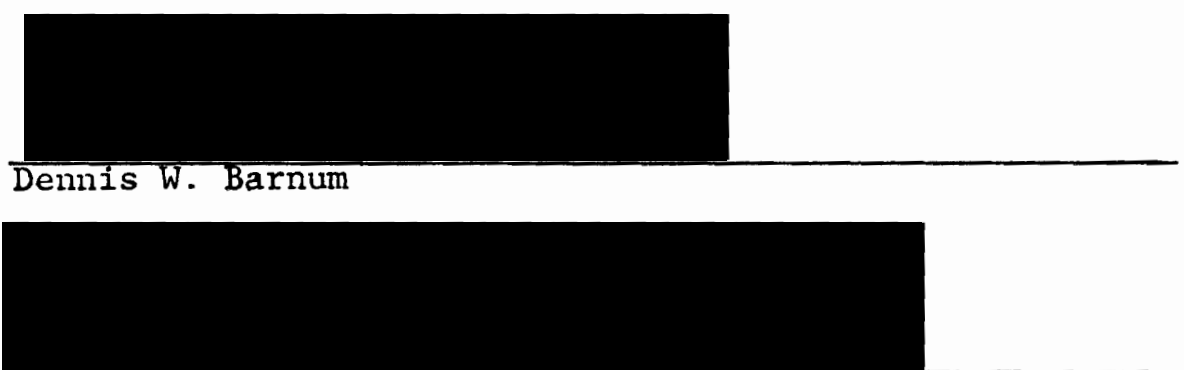

Raymond P. Lyzz

The photolytic reaction of 0 -methyl podocarpinitrile oxide to yield the $\delta$-lactam (shown below) was studied under various conditions such as: solvent (hexane, methanol), mercury lamp wattage (100W, 450W), filter (Pyrex, Corex, Vycor), and additives (dichloromethane, hexafluorobenzene). The reactions were analyzed with IR, NMR and HPLC. Preparative medium pressure liquid chromatography and TLC were used in the $\delta$-lactam isolation. The conditions resulting in the optimum yield of $\delta$-lactam were determined. The photolytic stability of the $\delta$-lactam under the conditions in which it was formed indicated that it was relatively stable only in hexane. 

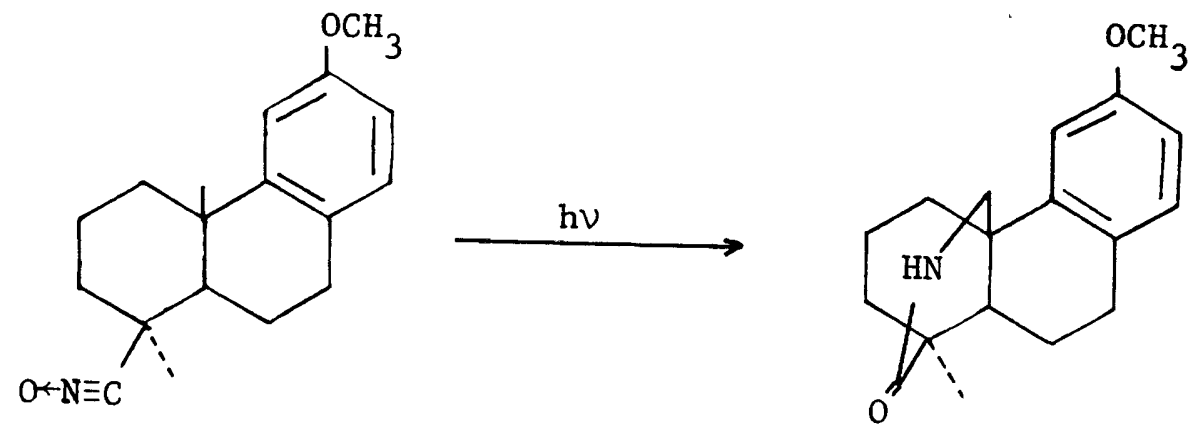

0-methyl podocarpinitrile oxide

$$
\delta-1 \text { actam }
$$




\section{A STUDY OF THE PHOTOLYSIS \\ OF O-METHYL PODOCARPINITRILE OXIDE}

by

Dianne Marie Hunter

a thesis submitted in partial fulfillment of the requirements for the degree of

\section{MASTER OF SCIENCE}

in

\section{CHEMISTRY}

Portland State University

1980 
TO THE OFFICE OF GRADUATE STUDIES AND RESEARCH:

The members of the Committee approve the thesis of Dianne Marie Hunter, presented February 22, 1980.

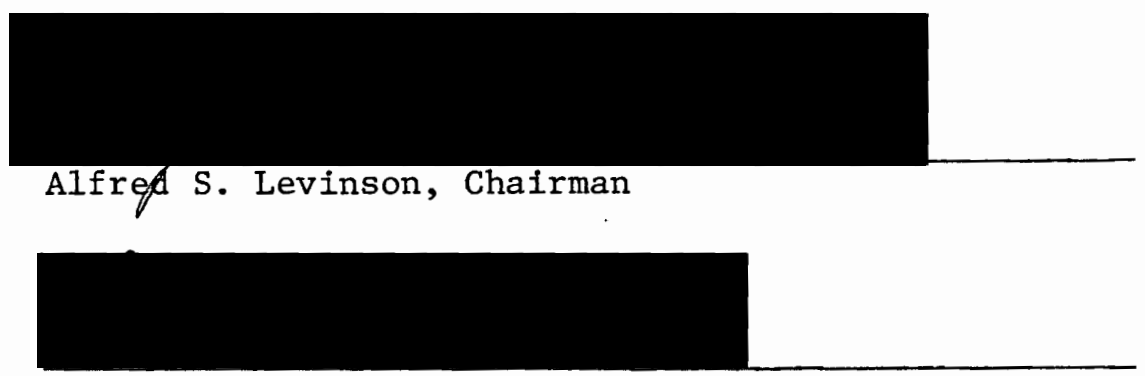

Dennis W. Barnum

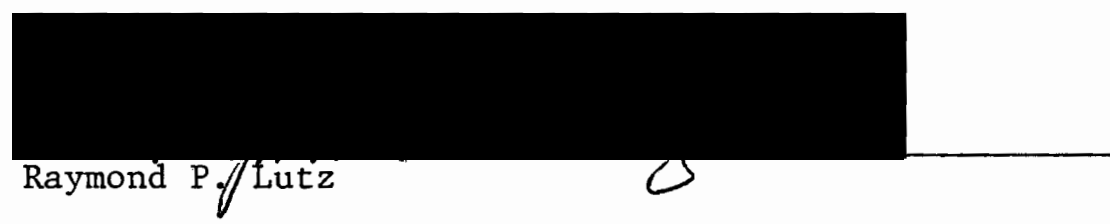

APPROVED :

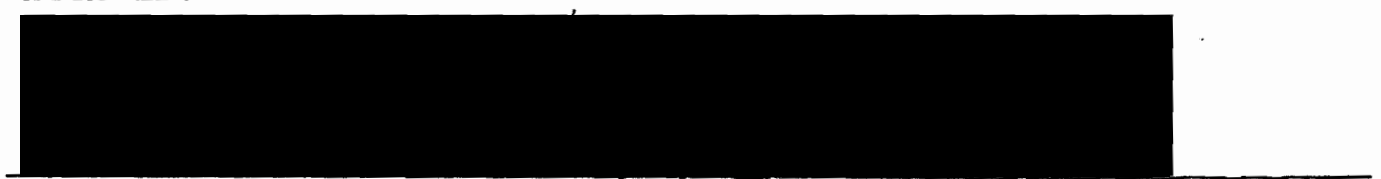

David W. McClure, Head, Department of Chemistry

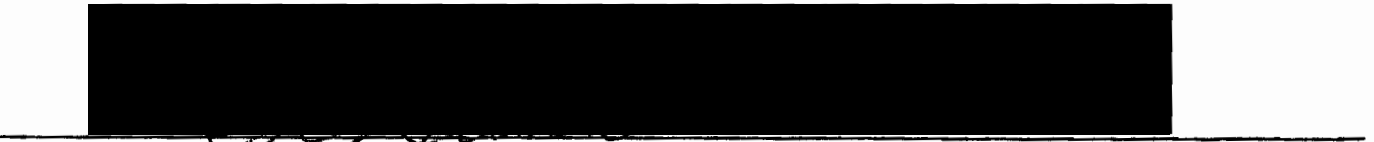

Stanley E. Kauch, Dean of Graduate Studies and Research 
Photolysis of $\delta$-lactam [2]

Photolysis of Anisole

VI CONCLUSIONS . . . . . . . . . . . . . . . 43

VII SUGGESTIONS FOR FUTURE WORK . . . . . . . . . . . 45

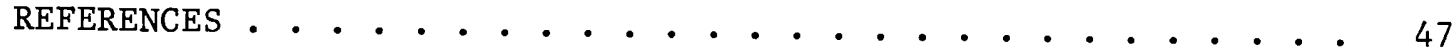

APPENDIX A: Applications of Nitrile Oxide 1,3-Dipolar

Cycloaddition . . . . . . . . . 50

B: Reactions of Nitrile Oxides with Nucleophiles . . 52

C: $\delta$-lactam Preparations . . . . . . . . . . 55 


\section{ACKNOWLEDGMENTS}

I would like to thank Dr. Alfred Levinson for his valuable assistance and advice throughout this project. I would also like to thank Dr. Gary Gard for the use of the photolysis cell, Dr. O. E. Edwards, of the National Research Council of Canada for an analytical sample of the $\delta$-lactam, Dr. George Just, of McGill University, for a copy of Werner Zehetner's Ph.D. thesis, and Mr. Allen Ryall, of the Oregon Graduate Center, for repairing the quartz cold finger.

Finally, I thank my family and friends for their support. 


\section{LIST OF TABLES}

TABLE

PAGE

I Effect of Additives on the Yield of Carbonyl-

nitrene Insertion Products . . . . . . . .

II Summary of Photolysis Conditions of O-methyl

podocarpinitrile oxide [1] and $\delta$-lactam [2] . .

III Summary of 0-methyl podocarpinitrile oxide [1]

Photolyses in Hexane . . . . . . . . . . .

IV Summary of 0-methyl podocarpinitrile oxide [1]

Photolyses in Hexane-dichloromethane . . . . .

$\mathrm{V} \quad$ Photolyses of 0-methyl podocarpinitrile oxide [1]

in Methanol with a 450 Watt or 100 Watt Mercury

Lamp . . . . . . . . . . . . . . . .

VI Summary of 0-methyl podocarpinitrile oxide [1]

Photolyses in Methanol with Filters . . . . .

VII Summary of 0-methyl podocarpinitrile oxide [1]

Photolyses in Methanol-dichloromethane . . . .

VIII Photolyses in Methanol-hexafluorobenzene . . . .

IX Summary of $\delta$-lactam [2] Photolyses . . . . . .

X Summary of Methyl 0-methyl podocarpate [21]

Syntheses . . . . . . . . . . . . . . 
TABLE

PAGE

XI Summary of O-methyl podocarpinol [22]

Syntheses . . • . . . . . . . . . . .

XII Summary of 0 -methyl podocarpinal [23]

Syntheses . . . . . . . . . . . . . .

XIII Summary of 0 -methyl podocarpinaldoxime [24]

Syntheses . . . . . . . . . . . . . . 35

XIV Summary of 0-methyl podocarpinitrile oxide [1]

Syntheses . . . . . . . . . . . . . . . 36

XV Summary of Anisole Photolyses in Hexanedichloromethane . . . . . . . . . . . . 41

XVI Summary of Anisole Photolyses in Methanoldichloromethane . . . . . . . . . . . . .

XVII High Pressure Liquid Chromatography Results of Reaction Products . . . . . . . . . . . 42 


\section{LIST OF FIGURES}

FIGURE

PAGE

1. Preparation of 0-methyl podocarpinitrile oxide [1] . . 14

2. Photolysis Apparatus . . . . . . . . . . . . 17

3. Effect of Wattage on the Formation of $\delta$-lactam [2]. - 21

4. Transmission Characteristics of the Filters . . . . . 22

5. Effect of Filters on the Formation of $\delta$-1actam [2] . . 23

6. Effect of Adding Dichloromethane on $\delta$-lactam [2]

Formation and Nitrile Oxide Disappearance . . . . . 24

7. Effect of Adding Hexafluorobenzene on $\delta$-lactam [2]

Formation in Methano1 . . . . . . . . . . . 25

8. Preparative Liquid Chromatograph Schematic Diagram . . 30 
CHAPTER I

\section{INTRODUCTION}

The nitrile oxide, until recently a relatively obscure function group, has been reported to be capable of undergoing a photolytic reaction resulting in the formation of lactams. 0-methyl podocarpinitrile oxide is the only known stable aliphatic nitrile oxide. Only two examples of this reaction are known, shown below.

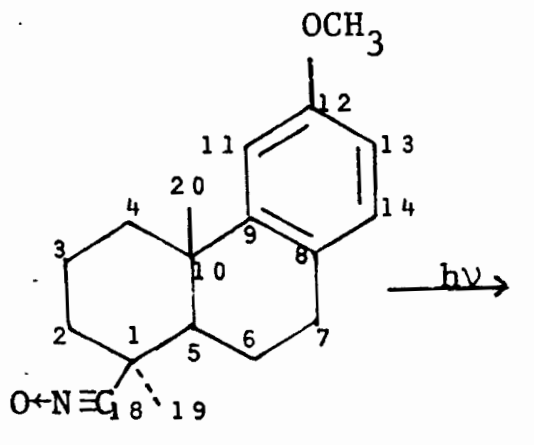

0-Methyl podocarpinitrile oxide

[1]<smiles>Cc1cc(C)c(C#N)c(C)c1</smiles>

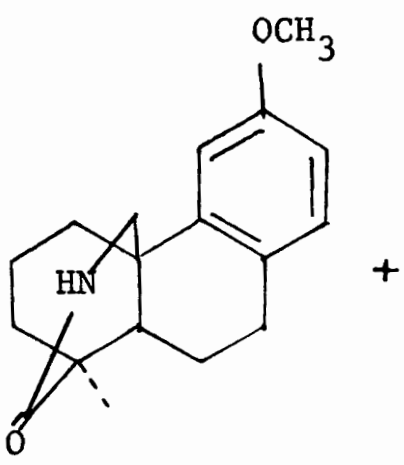

$\delta-\operatorname{lactam}(25 \%)$

[2]<smiles>COc1ccc2c(c1)C1(C)CC3CCC1C(C)(C3)C(=O)N2</smiles>

$\delta$-lactam $(<5 \%)$<smiles>Cc1cc(C)c2c(c1)CNC2OCc1cc(C)c(N=C=O)c(C)c1</smiles> 
Both of these examples were reported in preliminary form in the same publication over ten years ago. ${ }^{1}$ No further work in this area has been published. Because of a long-standing interest in this laboratory in the photolytic formation of lactams, a study of this little known reaction was initiated.

The first objective of this work was to determine if the reaction as reported was reproducible.

The second objective was to study whether or not the yields and/or products reported for this reaction were changed by variations in the reaction conditions. One aspect of this part of the work was to determine the conditions for optimizing the yield of $\delta$-lactam [2]. Another aspect was to determine if conditions believed to affect a proposed intermediate in this reaction, an acyl nitrene, had an effect in this case that would support or argue against the proposal. 
DESCRIPTION OF THE PROBLEM

\section{BRIEF HISTORY OF NITRILE OXIDES}

Werner ${ }^{2}$ in 1894 , discovered benzonitrile oxide ( $\emptyset \mathrm{CNO}$ ). The method of synthesis he used was the following equation.

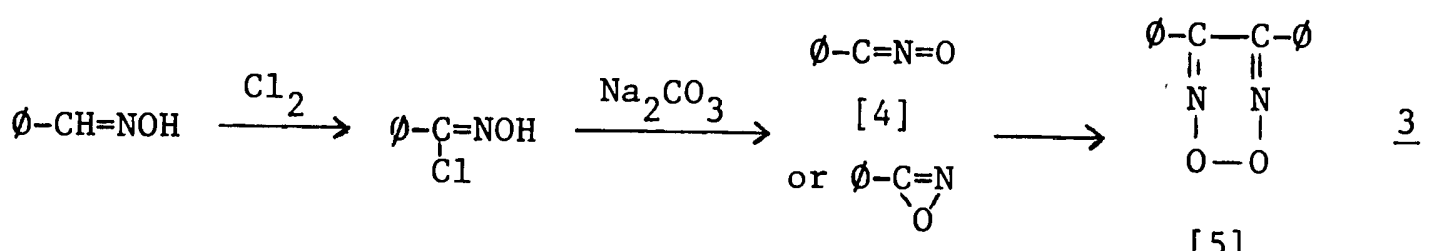

He proposed structure [4] for the nitrile oxide because it best explained the dimerization to what was thought to be [5]. Subsequently the dimerization product was shown to be [6].

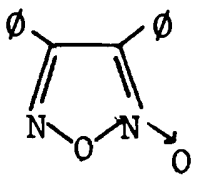

furoxan [6]

Wieland ${ }^{3}$, in 1907, purified benzonitrile oxide, having used Werner's synthetic procedure, determined its molecular weight, and studied some addition reactions. He made the statement that benzonitrile oxide was comparatively inert, incapable of giving additional reactions, and less reactive than the corresponding nitrile. Nitrile oxide chemistry was neglected during the next forty years, perhaps as 
a result of his statement.

Pauling ${ }^{4}$, in 1926, calculated the potential energies of all of the possible resonance forms of fulminic acid (HCNO) and concluded that the more important forms were:

$$
\begin{aligned}
& \oplus \theta \quad \oplus . . \theta \\
& \mathrm{HC} \equiv \mathrm{N}-\ddot{\mathrm{O}}: \leftrightarrow \quad \mathrm{HC}=\mathrm{N}-\ddot{\mathrm{O}}:
\end{aligned}
$$

He also showed that the addition reactions of fulminic acid could be understood in terms of the charged species [7].

Quilico ${ }^{5}$, in 1946, studied the chemistry of fulminic acid and its higher homologs. He showed that the nitrile oxides have an enhanced reactivity similar to that of aliphatic diazo compounds and azides, and that oxazoles were formed from nitrile oxides with olefins or acetylenes.

Huisgen ${ }^{6}$, in 1961, developed the 1,3 dipolar cycloaddition reaction of nitrile oxides, making some hitherto inaccessible heterocyclic systems possible and explaining some previously reported reactions. (Refer to Appendices A and B for examples.)

Grundmann $^{7}$, in 1964 , discovered that steric hindrance on the $R$ group can be used to control the dimerization of nitrile oxides (Eqn. 5) without affecting their general reactivity.

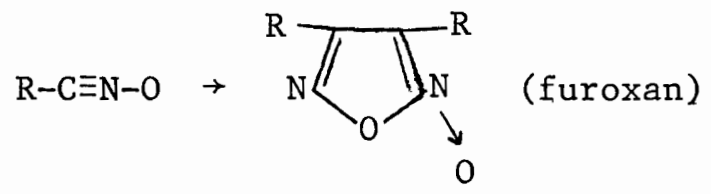


The only photolyses of nitrile oxides carried out were done by Just and Zehetner ${ }^{1,8}$. (Equations 1 and $\underline{2}_{.}$)

\section{PREPARATION OF NITRILE OXIDES}

The known methods of nitrile oxide syntheses start with a system containing the $\mathrm{C}-\mathrm{N}-\mathrm{O}$ sequence. The most important methods start with aldoximes, from which two hydrogen atoms are abstracted by various means to form the nitrile oxide.

$$
\mathrm{R}-\mathrm{CH}=\mathrm{N}-\mathrm{OH} \stackrel{-2 \mathrm{H}}{\longrightarrow} \mathrm{R}-\mathrm{C} \equiv \mathrm{N} \rightarrow \mathrm{O}
$$

Some of the methods use alkaline ferric cyanide, alkaline hypohalites, $\mathrm{N}$-bromosuccinimide in the presence of alkali alkoxides ${ }^{9}$, tertiary bases $^{10}$, or lead tetraacetate ${ }^{11}$ as the dehydrogenating reagent. Only syn-oximes [8] ${ }^{12}$ lead to nitrile oxides as shown:<smiles>[R]/C=N\O</smiles>

[8]<smiles>[R]C=[Y]O[R6]([R])([H])O[Na]</smiles><smiles>[R]C1=NO[Pb]([R4])([R4])O[Z]1([R])[Na]</smiles>

$\mathrm{R}-\mathrm{C} \equiv \mathrm{N} \rightarrow \mathrm{O}+\mathrm{Pb}(\mathrm{OAC})_{2}+\mathrm{HOAC}$

Anti-oximes [9] follow a different course, leading to nitroso acetate dimers:<smiles>[R]C=NO</smiles>

[9]

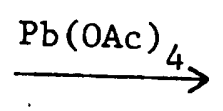<smiles>[R10]OC([R])[N+](=O)N=[N+]([O-])C([R])OC(C)=O</smiles>

(Nitroso acetate dimers) 8 
Another method uses hydroxamic acid chloride [10] to form nitrile oxide upon dehydrochlorination with a base such as pyridine ${ }^{12}$.

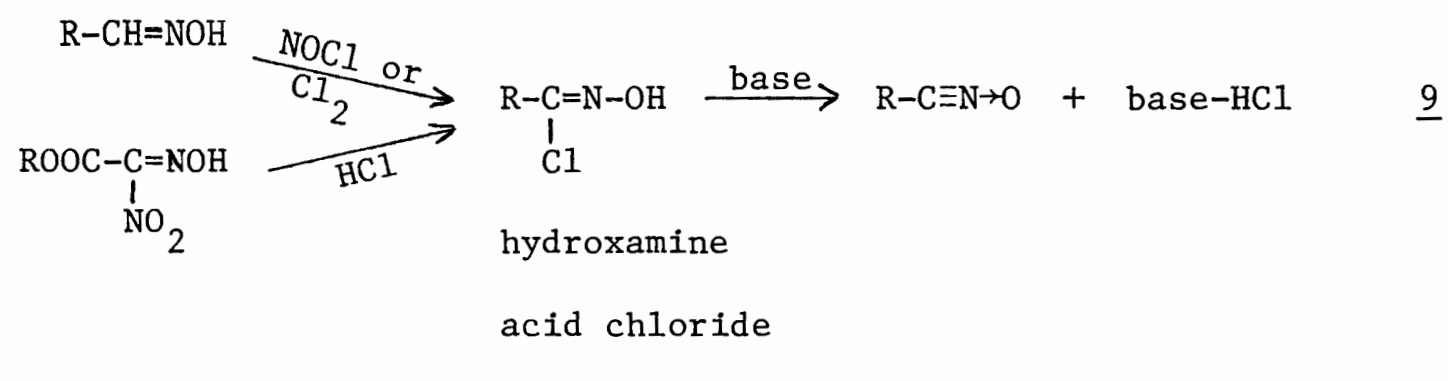

The in situ preparation of the nitrile oxide, in the presence of a substance with which it will react about as fast as with itself, helps deal with its extreme reactivity. The nitrile oxide is generated slowly in the presence of a high concentration of the reaction partner.

REACTIONS OF NITRILE OXIDES

1,3 Dipolar Cycloaddition. The general equation for this type of reaction is:

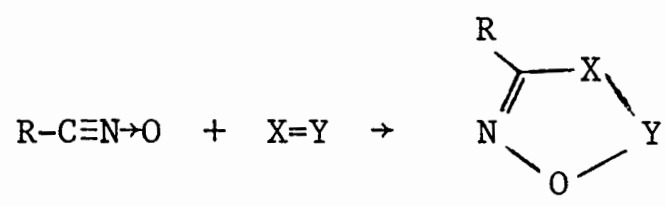

with either electron rich or poor unsaturated systems. Examples of this type are given in Appendix A.

1,3 Addition. Nucleophilic attack on the carbon of the nitrile group results in 1, 3 addition, as shown below:

$$
\mathrm{R}-\mathrm{C} \equiv \mathrm{N} \rightarrow \mathrm{O}+\mathrm{HB} \rightarrow{ }_{\mathrm{H}}^{\mathrm{B}}>\mathrm{C}=\mathrm{N}-\mathrm{OH}
$$


Some general examples illustrating the ability of nitrile oxides to react with a large number of nucleophiles to yield open chain 1,3 addition products are to be found in Appendix B.

Isomerization to isocyanates. Heating a nitrile oxide above its limit of thermal stability initiates two reactions. The most frequent reaction is dimerization to furoxans (eqn. 5) which can be prevented by steric hindrance. The other reaction is the rearrangement to isocyanates [12] (eqn. 12). The mechanism of the thermal rearrangement to isocyanates is not known.

$$
\mathrm{R}-\mathrm{C} \equiv \mathrm{N} \rightarrow \mathrm{O} \rightarrow \mathrm{R}-\mathrm{N}=\mathrm{C}=\mathrm{O} \quad \text { (isocyanate) }
$$

A mechanism suggested by Grundmann ${ }^{13}$ for the isomerization is:

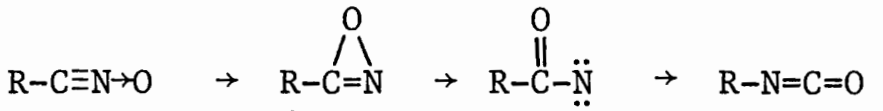

$$
\begin{aligned}
& \text { oxazirene alkanoyl- isocyanate } \\
& \text { [13] nitrene } \\
& \text { [14] }
\end{aligned}
$$

There has been little evidence to support this mechanism. The alkanoylnitrene [14] has not been trapped with cyclohexene and there is no UV or IR evidence for the oxazirene [13] ${ }^{13}$.

Photolysis. There have been two reported photolyses of nitrile oxides $^{1}$. The photolysis of 0-methyl podocarpinitrile oxide [1] gave the same lactams ([2] and [3]) as were obtained from the photolysis of the acyl azide of 0-methyl podocarpic acid ${ }^{14}$ [15] shown below. 


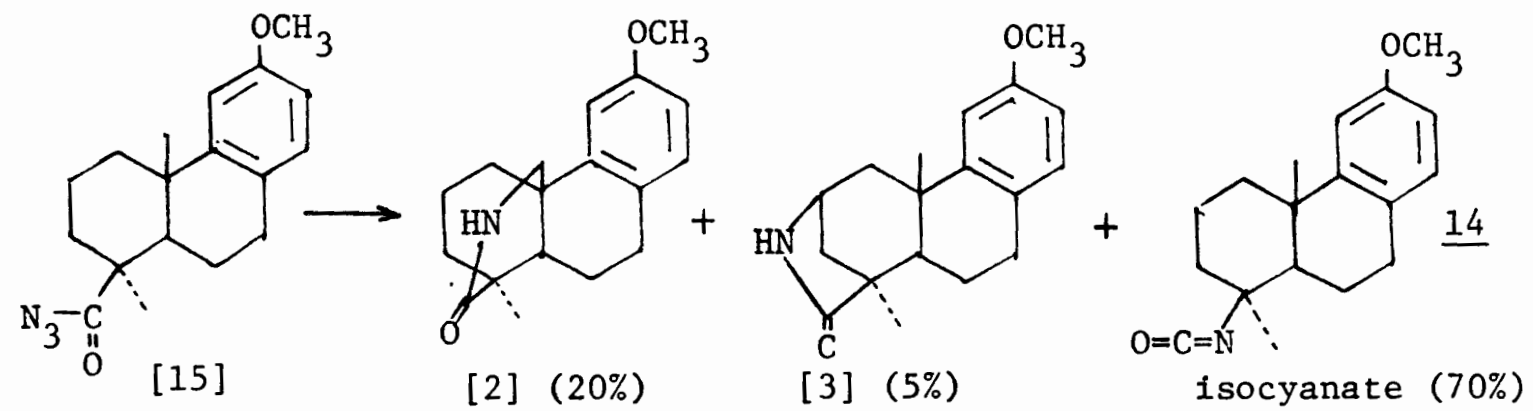

Acyl azides are believed to react via the unstable alkanoylnitrene. Just ${ }^{1}$ proposed a mechanism for the photolytic conversion of the nitrile oxide to the $\delta$ and $\gamma$ lactams with an oxazirene [16] and an alkanoylnitrene [17] as intermediates, shown below:

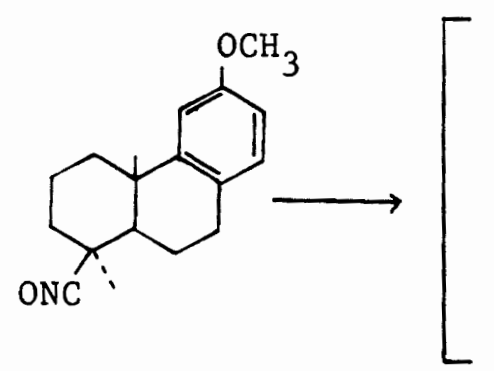

[1]

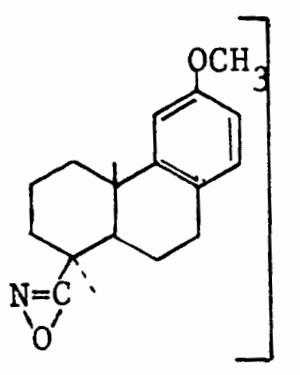

[16]

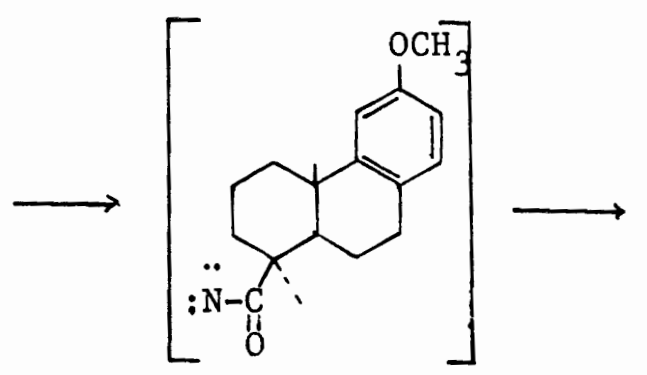

[17]

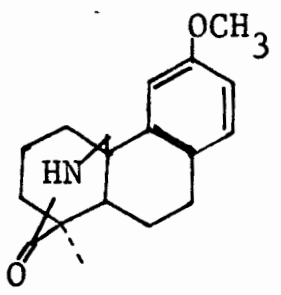

[2]

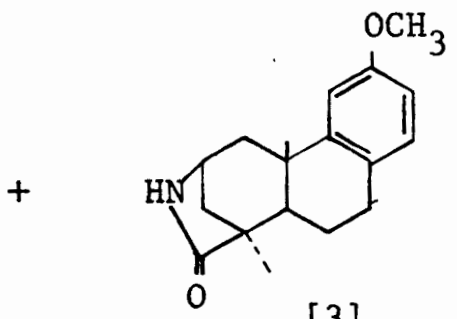

[3]

The relationship between the photolysis of nitrile oxides and the photolysis of acyl azides is found in the common product, a lactam, and the possible common intermediate, an alkanoylnitrene. This relationship is central to this work and detailed discussion of the acyl azide photolysis will lead to logical suggestions for study of nitrile oxide photolysis. 
CARBONYLNITRENES

There are two kinds of carbonylnitrenes: alkanoylnitrenes [18] and alkoxycarbonylnitrenes [19].
$R-\stackrel{O}{\|}-\ddot{N}: \quad R-\stackrel{O}{\|}-\ddot{N} \cdot$
singlet triplet

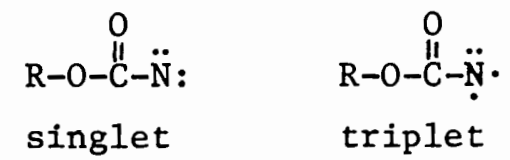

[18]
[19]

Singlet and triplet states can be detected by electron spin resonance, ultraviolet, and by product stereochemistry. ${ }^{15}$

Carbonylnitrenes are generated by elimination in the presence of a substrate. Much has been written about carbonylnitrenes, their formation and reactions. Nitrenes are able to insert into unactivated $\mathrm{C}-\mathrm{H}$ bonds, $\mathrm{O}-\mathrm{H}$ bonds, and $\mathrm{N}-\mathrm{H}$ bonds. Some examples of alkoxycarbonylnitrene $\mathrm{O}-\mathrm{H}$ and $\mathrm{N}-\mathrm{H}$ bond insertions are shown below.

$$
\begin{aligned}
& \text { EtOOC }-\mathrm{N}_{3} \underset{\mathrm{R}-\mathrm{CH}_{2} \mathrm{OH}}{\longrightarrow} \quad \text { EtOOC }-\mathrm{NH}-\mathrm{OCH}_{2} \mathrm{R} \\
& \mathrm{R}^{\prime}-\mathrm{OOC}-\mathrm{N}_{3} \underset{\mathrm{RNH}_{2}}{\stackrel{\mathrm{hV}}{\longrightarrow}} \mathrm{R}^{\prime} \mathrm{OOC}-\mathrm{NH}-\mathrm{NHR} \\
& \underset{\mathrm{R}_{2} \mathrm{NH}}{\mathrm{hV}} \text { R'OOC-NH-NR}{ }_{2}
\end{aligned}
$$

The Curtius rearrangement of alkanoylnitrenes to isocyanates is often a side reaction.

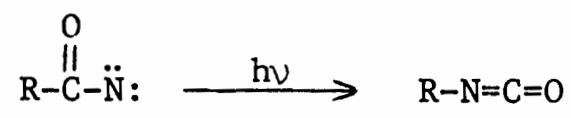

Dissociation of alkanoylnitrenes has also been reported as in the following proposed equation. 
$\mathrm{R}-\mathrm{C}-\ddot{\mathrm{N}}: \rightarrow \underset{\mathrm{R}-\ddot{\mathrm{C}}-\ddot{\mathrm{N}} \cdot}{\stackrel{O}{*}} \rightarrow \mathrm{R} \cdot+\cdot \mathrm{NCO} \rightarrow \underset{\text { polymers }}{\mathrm{HNCO}}+\underset{\text { compounds }}{\text { unsaturated }}$

There are several examples of lactam formation from alkanoylnitrenes shown below. (Other methods of $\delta$-lactam preparation can be found in Appendix C.)

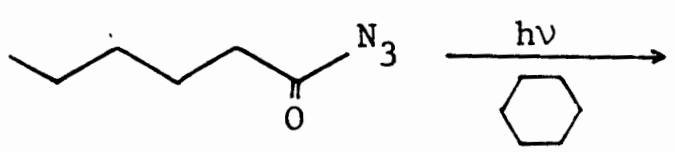

(ref. 16)<smiles>CC1CCCC(=O)N1</smiles>

$12 \%$ $23 \%$<smiles>CCCC1CCCC(=O)N1</smiles>
$12 \%$<smiles>CCC1CCC(=O)N1</smiles>

$5 \%$

$\underset{\mathrm{CH}_{2} \mathrm{Cl}_{2}}{\stackrel{h v}{\longrightarrow}}$<smiles>[Y3]C(=O)CCCCCCC</smiles>

(ref. 16, 17)

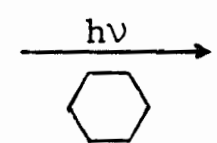

$\underset{\mathrm{CH}_{2}{ }^{\mathrm{Cl}} 2}{\longrightarrow}$<smiles>CC12CCCC(C)(C(N)=O)C1CC1CCCCC1C2</smiles>

(ref. 14)

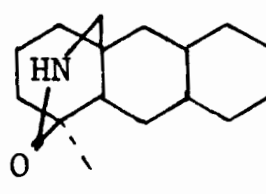

$25 \%$

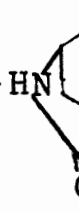

4

$5 \%$<smiles>CCCCC1CCC(=O)N1</smiles> 
The effect of the solvent on the electronic state of nitrenes has been studied. Solvents with heavy atoms are known to promote intersystem crossing of the singlet nitrenes to the triplet nitrenes.

Intersystem crossing is decreased in solvents providing suitable overlap with unshared electron pairs. Presumably, the unshared electron pairs stabilize the singlet nitrenes. Alkanoylnitrenes show insertion yields twice as large in dichloromethane as in cyclohexane. (Equations 20 and 21. ) It is assumed that dichloromethane stabilizes the insertion-active state of singlet nitrenes without removing the reactivity by solvation. There is no effect of dichloromethane on alkoxycarbonylnitrene insertions. According to Gleiter and Hoffmann ${ }^{18}$, singlet nitrene stabilization requires the symmetrical interaction of two unshared electron pairs with the nitrene. Perhaps there is no stabilization of alkoxycarbonylnitrenes because there is some interaction between the oxygen and nitrene electrons.

There are contradictory results about additives stabilizing singlet alkanoylnitrenes and alkoxycarbonylnitrenes. More studies have been done on singlet alkoxycarbonylnitrene stabilization.

One of the first reports in this area was by Lwowski 19,20 on alkanoylnitrenes insertion. It was noticed that the yield of insertion product was greater in dichloromethane than in neopentane. He concluded that in dichloromethane, there was less intersystem crossing. Breslow $^{21}, 22$ reported that alkoxycarbonylnitrenes in the presence of dinitrobenzene or hexafluorobenzene, gave higher insertion product yields. The optimum yields of insertion products were obtained with $0.27 \%$ dinitrobenzene in cyclohexane and with $10 \%$ hexafluorobenzene in cyclohexane. He postulated that the additives either functioned as 
as radical traps or that they formed complexes with the singlet nitrene, stabilizing them against intersystem crossing.

Felt ${ }^{23}$ also observed that alkoxycarbonylnitrenes are stabilized with hexafluorobenzene. His results with dichloromethane showed that the highest yield of insertion product (21\%) was obtained with $97 \%$ dichloromethane.

Belloli 24,25 studied the effect of dichloromethane and hexafluorobenzene on alkoxycarbonylnitrene insertion. His results show that dichloromethane has no effect on the yield but that a $10 \%$ hexafluorobenzene solution optimizes the insertion yield. He believes that this stabilization is the result of a singlet nitrene-halogen complex. The decrease in yield at higher additive concentrations was postulated to be the result of collisional deactivation.

Takeuchi ${ }^{26}$ studied the effect of 1,4 dioxane addition on an alkoxycarbonylnitrene. The optimum yield (65\%) of the photolytic insertion product was obtained with $97 \%$ dioxane in cyclohexane. He suggests thst this is the result of a nitrene-dioxane complex. Conflicting with this is the result that the thermal generation of the alkoxycarbonylnitrene is almost independent of dioxane.

A summary of these results is shown in Table I. 
TABLE I

EFFECT OF ADDITIVES ON THE YIELD OF

CARBONYLNITRENE INSERTION PRODUCTS

$\underline{\text { ADDITIVE }}$

Dichloromethane

Hexafluorobenzene

Dinitrobenzene

1,4 Dioxane

\section{ALKOXYCARBONYL- \\ NITRENE}

none

increase

increase

increase
ALKANOYL-

NITRENE

increase

none

unknown

unknown

Calculations made on carbonylnitrenes suggest that alkanoylnitrenes have a larger singlet-triplet separation than alkoxycarbonylnitrenes. 27 This could reduce the tendency of alkoxycarbonylnitrenes to undergo intersystem crossing and explain the different effects dichloromethane has on alkanoylnitrenes and alkoxycarbonylnitrenes.

Since it has been suggested ${ }^{8}$ that photolysis of the nitrile oxides proceeds via the isomeric alkanoylnitrene (eqn. 15), we undertook to restudy this reaction under a variety of conditions believed to affect the reactivity of alkanoylnitrenes. 


\section{DISCUSSION OF EXPERIMENTAL}

The synthesis of 0-methyl podocarpinitrile oxide [1] was carried out according to the following scheme.<smiles>CC1(C)CCCC2c3cc(O)ccc3CCC21</smiles>

[20]
$\underset{3}{\stackrel{\left(\mathrm{CH}_{3}\right)_{2} \mathrm{SO}_{4}}{\longrightarrow}}$
$\frac{\mathrm{CH}_{3} \mathrm{OH}}{\longrightarrow}$<smiles></smiles>

[21]<smiles>CCOC(=O)CCc1ccc(OC)cc1C1CCCC(C)(CO)C1CO</smiles>

[22]

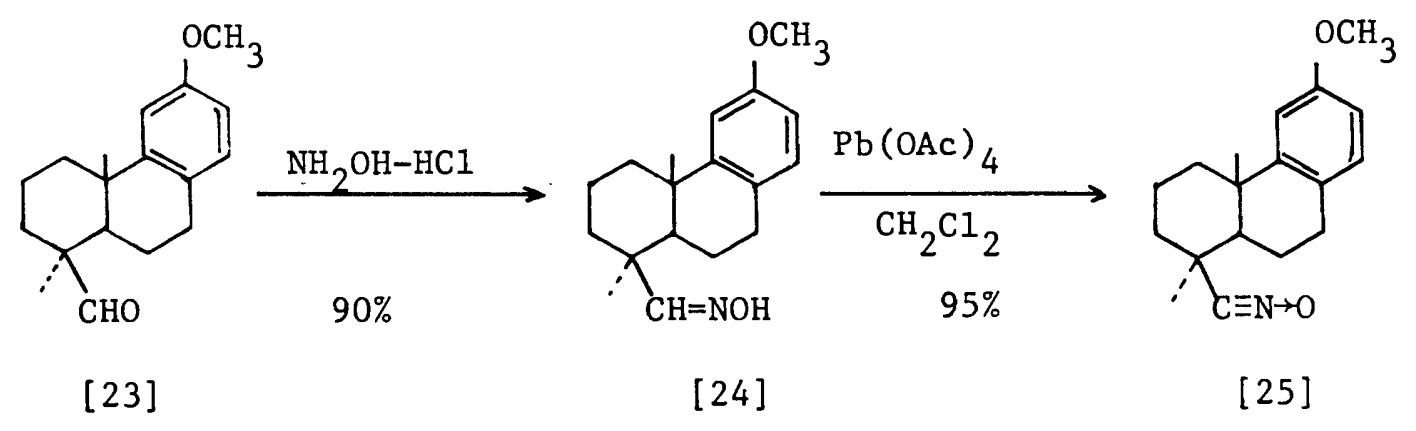

Figure 1. Preparation of 0-methyl podocarpinitrile oxide.

All yields were at least as good as those reported in the literature. The oxidation of the alcohol [22] to aldehyde [23] was carried out by a new method. Previous workers used chromium trioxide and 
sulfuric acid. ${ }^{8}$ The development of pyridinium chlorochromate [28] as a selective oxidizing agent afforded us with a new route. This reaction gave aldehyde [23] in higher yield than had been previously obtained. Inexplicably, the melting point of our aldehyde [23] did not agree with previous reports. All other melting points agreed with literature values. We did observe, however, that good yields of aldoxime [24] did depend on using recrystallized aldehyde [23] and that the NMR of aldehyce [23] showed the same doublet for the aldehyde proton as has been reported. 29

The nitrile oxide [1] was obtained in overall yield of $41 \%$ from commercial podocarpic acid [18] (five steps).

The variables selected for study in the photolysis of 0 -methy 1 podocarpinitrile oxide [1] were: solvent (methanol or hexane), mercury lamp (450w or 100w), filter (Pyrex, Corex, Vycor (see figure 5)) and additive (hexafluorobenzene or dichloromethane). A diagram of the photolysis apparatus is shown in Figure 2. By removing aliquots for analysis in many experiments, the progress of the reaction with time was also followed.

In addition, the product of interest from the photolysis,

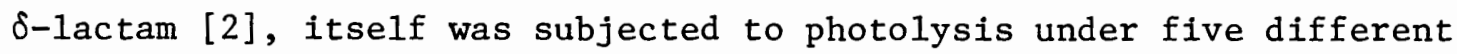
conditions to determine its stability under the various reaction conditions.

The thermal stability of 0-methyl podocarpinitrile oxide [1] was studied by refluxing in hexane or methanol for six hours. There was no evidence of any reaction by high pressure liquid chromatography and infrared analysis. 
The workup procedure depends on the solvent. In hexane, $\delta$-lactam [2] is insoluble. It is collected by filtration. The resulting filtrate is concentrated to yield additional crude $\delta$-lactam [2]. The concentrated filtrate is analyzed by HPLC.

However, in methanol, $\delta$-lactam [2] is soluble. These reactions were analyzed at approximate hourly intervals by HPLC, monitoring $\delta$-lactam [2] and nitrile oxide [1]. The solution was then concentrated to an oil.

\section{TABLE II}

SUMMARY OF PHOTOLYSIS CONDITIONS OF

O-METHYL PODOCARPINITRILE OXIDE [1]

AND $\delta$-LACTAM [2]

\begin{tabular}{lcclcl} 
SOLVENT & LAMP $(\mathrm{W})$ & FILTER & COMPOUND & ADDITIVE & TIME (HRS.) \\
\hline hexane & 450 & - & CNO [1] & - & $2.0,5.0,8.0$ \\
hexane & 450 & - & CNO [1] & $\mathrm{CH}_{2} \mathrm{Cl}_{2}$ & $2.0,6.5,8.0$ \\
MeOH & 450 & - & CNO [1] & - & $3.4,5.5,6.1$ \\
MeOH & 100 & Pyrex & CNO [1] & - & $3.0,3.9,4.7$ \\
MeOH & 100 & Corex & CNO [1] & - & $5.7,6.1$ \\
MeOH & 100 & Vycor & CNO [1] & - & $3.5,5.0$ \\
MeOH & 450 & - & CNO [1] & $\mathrm{CH}_{2} \mathrm{Cl}_{2}$ & $5.4,5.7,6.0$ \\
MeOH & 450 & - & CNO [1] & $\mathrm{F}_{6} \mathrm{C}_{6}$ & $1.5,5.5$ \\
& & & & & \\
hexane & 450 & - & $\delta$-lactam [2] & - & 3.5 \\
hexane & 450 & - & $\delta$-lactam [2] & $\mathrm{CH}_{2} \mathrm{Cl}_{2}$ & 3.5 \\
MeOH & 450 & - & $\delta$-lactam [2] & - & 3.4 \\
MeOH & 450 & - & $\delta$-lactam [2] & $\mathrm{CH}_{2} \mathrm{Cl}_{2}$ & 2.0 \\
MeOH & 450 & - & $\delta$-lactam [2] & $\mathrm{F}_{6} \mathrm{C}_{6}$ & 3.8
\end{tabular}




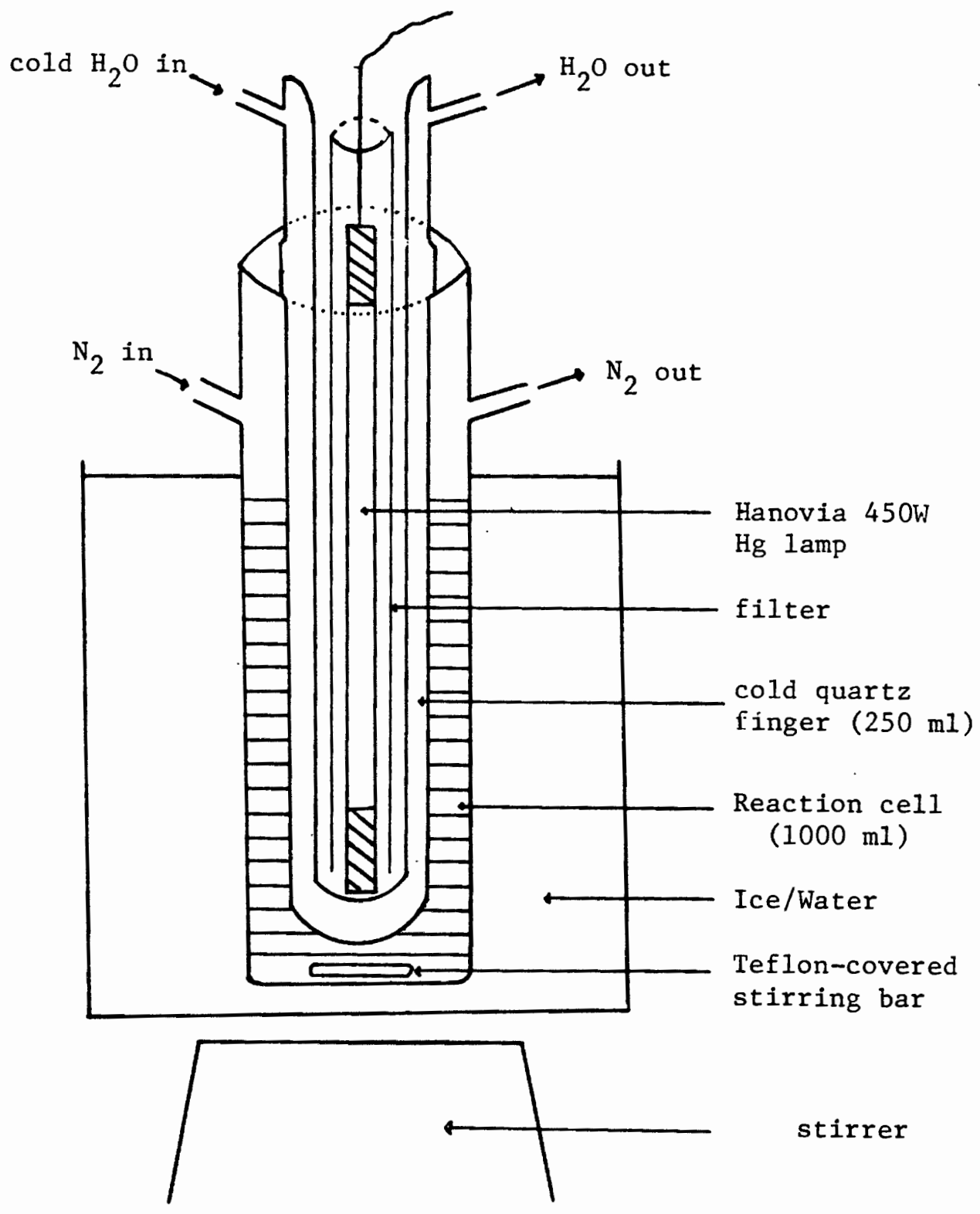

Figure 2. Photolysis apparatus 
CHAPTER IV

RESULTS

\section{O-METHYL PODOCARPINITRILE OXIDE [1] PHOTOLYSES}

1. Hexane. Photolyses of 0-methyl podocarpinitrile oxide [1] were performed in hexane and hexane-dichloromethane mixtures for periods of two to eight hours. The volume of hexane was kept constant while employing molar ratios of nitrile oxide to dichloromethane of one to one and one to ten.

Photolyses with the 450 watt mercury lamp in hexane gave the $\delta-1$ actam [1] in crude yields of $50-60 \%$. Some of the product formed on the cold finger surface. This formation might have reduced the

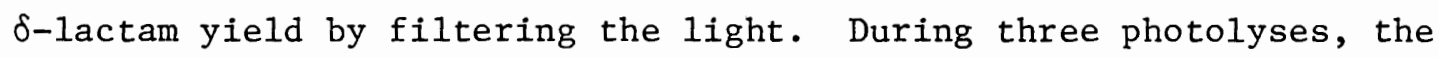
solid was rinsed off the cold finger with methanol, followed by hexane every hour. The crude yield increased to $85 \%$ and $90 \%$ in two photolyses and decreased to $31 \%$ in the third under the same conditions.

Analysis of the crude solids by high pressure liquid chromatography indicated mostly $\delta$-1actam [2] with a small amount of $\gamma$-1actam [3]. The concentrated filtrates showed peaks corresponding to the presence of the lactams $\delta$-lactam [2], $\gamma$-lactam [3], some starting nitrile oxide [1], and many side products.

Zehetner ${ }^{8}$ photolyzed 300 mg 0-methyl podocarpinitrile oxide in $75 \mathrm{ml}$ hexane $(0.4 \% \mathrm{w} / \mathrm{v})$ for two hours. He recovered $75 \mathrm{mg}(25 \%)$ crude $\delta$-lactam [2], which was purified by sublimation. Photolysis in 
hexane for longer times, up to forty hours, resulted in approximately the same yields.

\section{TABLE III}

SUMMARY OF O-METHYL PODOCARIPNITRILE OXIDE PHOTOLYSES IN HEXANE

\begin{tabular}{ccccccr} 
& & mg NITRILE & mg CRUDE $\delta-$ & $\%$ YIELD & mg \\
REACTION & HOURS & OXIDE [1] & LACTAM [2] & CRUDE [2] & RECRYST. & mp \\
\hline 1 & 2.0 & 199 & 40 & 20 & - & 230 \\
2 & 2.0 & 201 & 105 & 42 & - & $220-240$ \\
3 & 5.0 & 173 & 101 & 58 & - & $220-240$ \\
$4^{a}$ & 8.0 & 203 & 173 & 85 & - & $220-255$ \\
$5^{a}$ & 8.0 & 204 & 64 & 31 & - & $230-265$ \\
6 & 2.5 & 1000 & 440 & 44 & 210 & 270 \\
7 & 2.5 & 1000 & 460 & 46 & 327 & $266-267$ \\
$8^{a}$ & 6.0 & 205 & 187 & 91 & &
\end{tabular}

a Cold finger occasionally rinsed with methanol and then hexane to remove the crude solid.

Photolyses of the nitrile oxide [1] in hexane-dichloromethane mixtures gave less $\delta$-lactam [2] than photolyses in hexane alone. The I:10 (RCNO: $\mathrm{CH}_{2} \mathrm{Cl}_{2}$ ) mixture formed less product than the $1: 1\left(\mathrm{RCNO}: \mathrm{CH}_{2} \mathrm{Cl}_{2}\right)$ mixture. The color of the concentrated filtrates from the 1:10 mixture was a darker brown than the 1:1 mixture, which was a darker color than the photolyses in hexane alone. The solid that formed on the cold finger, could not be rinsed off with methanol. Analysis of the crude solids and concentrated filtrates by high pressure liquid chromatography indicated many more peaks than the analyses of the 
photolyses without dichloromethane. It appears that the addition of dichloromethane caused the decomposition of either the nitrile oxide or of the $\delta$-lactam [2].

TABLE IV

SUMMARY OF O-METHYL PODOCARPINITRILE OXIDE PHOTOLYSES

IN HEXANE-DICHLOROMETHANE

\begin{tabular}{cccccccc} 
REACTION & HOURS & $\begin{array}{c}\text { MITRILE } \\
\text { OXIDE [1] }\end{array}$ & $\begin{array}{c}\mu L \\
\mathrm{CH}_{2} \mathrm{Cl}_{2}\end{array}$ & $\begin{array}{c}\mathrm{MOLES} \\
\mathrm{CNO}{ }_{2} \mathrm{Cl}_{2}:\end{array}$ & $\begin{array}{c}\mathrm{mg} \\
\text { CRUDE } \\
\text { [2] }\end{array}$ & $\begin{array}{c}\text { CRUDE } \\
\text { YIELD }\end{array}$ & mp \\
\hline 1 & 6.5 & 206 & 450 & 10 & 32 & 16 & $<190^{\circ}$ \\
2 & 8.0 & 201 & 45 & 1 & 88 & 44 & $<190^{\circ}$ \\
3 & 2.8 & 221 & 45 & 1 & 61 & 28 & $273^{\circ}$
\end{tabular}

2. Methanol. Photolyses of 0-methyl podocarpinitrile oxide [1] were performed in methanol, methanol-dichloromethane, and methanolhexafluorobenzene mixtures for periods of three to six hours. The volume of methanol was kept constant while employing a one to one molar ratio of nitrile oxide to dichloromethane and of nitrile oxide to hexafluorobenzene. The product was soluble in methanol and its formation could be directly monitored by high pressure liquid chromatography.

Nitrile oxide [1] was irradiated with a 100 watt. or a 450 watt mercury lamp. The 450 watt lamp gave the greater yield of $\delta$-lactam [2]. The reaction appeared to stop after two hours with nitrile oxide [1] still present. 
TABLE V

PHOTOLYSES OF O-METHYL PODOCARPINITRILE OXIDE [1]

IN METHANOL WITH A 450 OR 100 WATT MERCURY LAMP

REACTION

1 FILTER HOURS

3.4

6.1

5.5

5.4

6.0

5

$-$ WATTAGE mg NITRILE OXIDE [1] 214

219

203

180

208

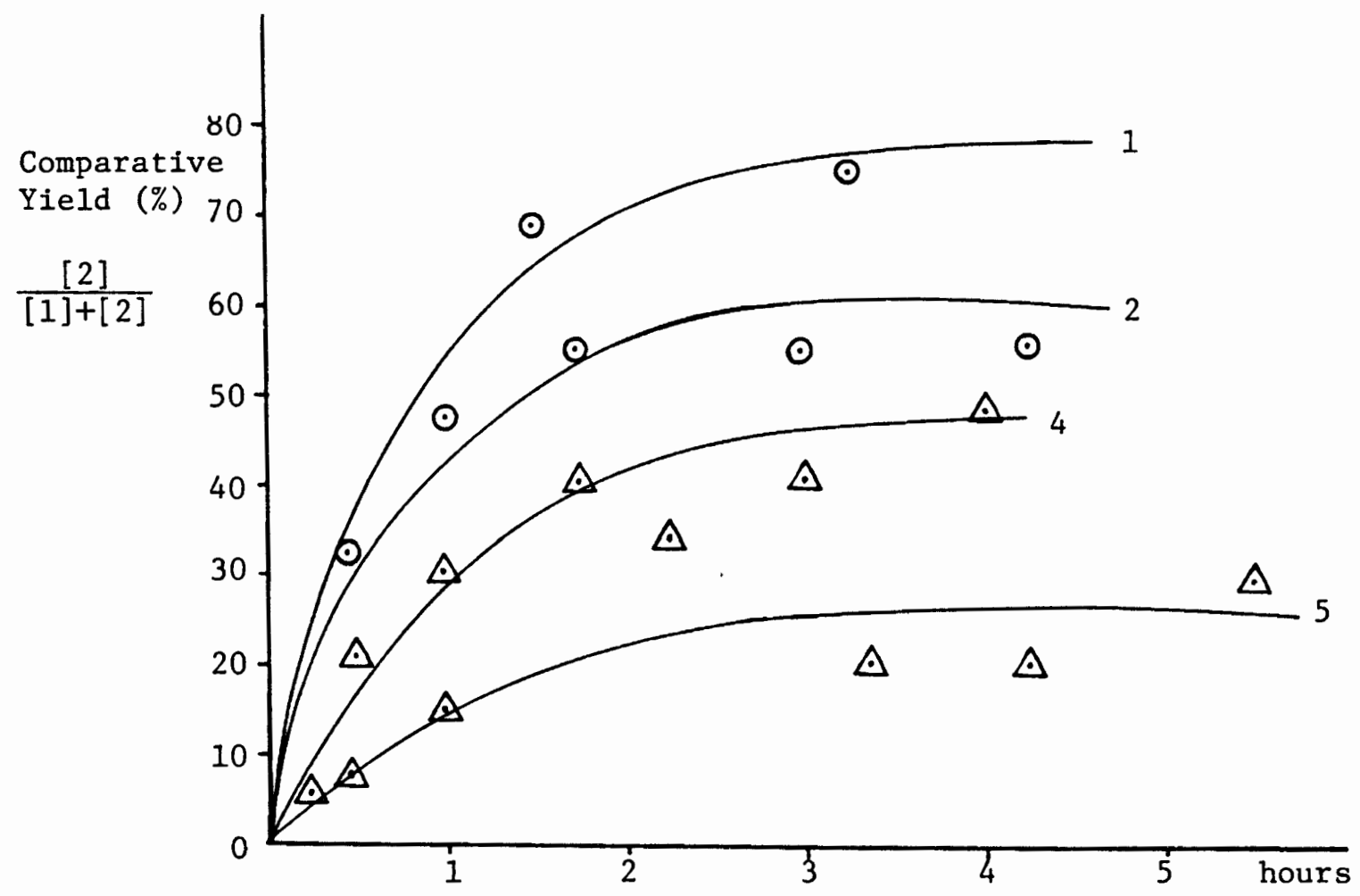

Figure 3. Effect of wattage on the formation of $\delta$-lactam [2]. Refer to Table $V$ for identification. 
Some photolyses employed filters (Figure 4) with the 100 watt lamp to determine the best wavelength of irradiation. (The 450 watt lamp became overheated and formed an opaque yellow film on the filter and hence was not used with filters.) The yield decreased as the higher energy irradiation was filtered (Pyrex < Corex < Vycor < no filter) as shown in Figure 5 .

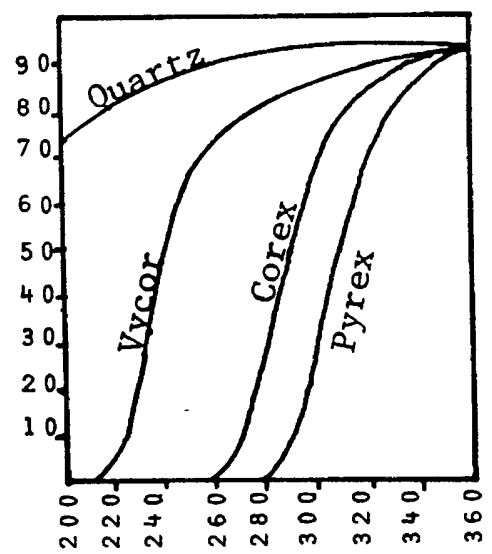

Figure 4. Transmission characteristics of the filters. 
TABLE VI

SUMMARY OF O-METHYL PODOCARPINITRILE OXIDE [1] PHOTOLYSES IN METHANOL WITH FILTERS

\begin{tabular}{ccccc} 
REACTION & FILTER & HOURS & $\begin{array}{c}\text { LAMP } \\
\text { WATTAGE }\end{array}$ & $\begin{array}{c}\text { mg NITRILE } \\
\text { OXIDE [1] }\end{array}$ \\
\hline 1 & Pyrex & 4.7 & 100 & 201 \\
2 & Pyrex & 3.9 & 100 & 190 \\
3 & Pyrex & 3.0 & 100 & 199 \\
4 & Vycor & 3.5 & 100 & 200 \\
5 & Vycor & 5.0 & 100 & 200 \\
6 & Corex & 5.7 & 100 & 205 \\
7 & Corex & 6.1 & 100 & 213
\end{tabular}

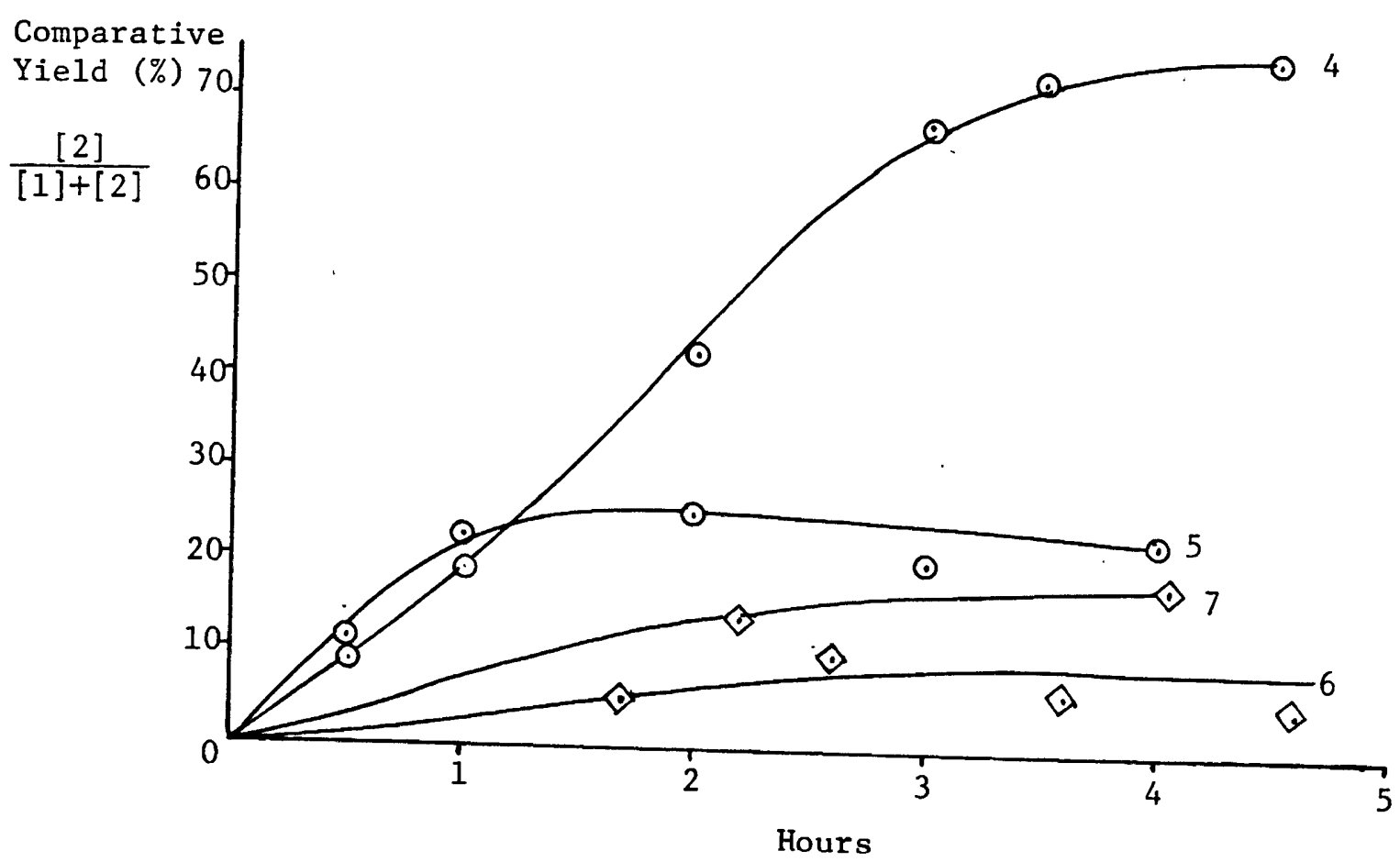
Figure 5
Refer to
Table VI and Figure 4 . 
Photolyses of 0-methyl podocarpinitrile oxide [1] in hexanedichloromethane gave $\delta$-lactam in smaller yields than in methanol alone.

TABLE VII

SUIMARY OF O-METHYL PODOCARPINITRILE OXIDE PHOTOLYSES IN METHANOL-DICHLOROMETHANE

REACTION

1

2

3 mg NITRILE OXIDE [1]

HOURS

199

6.0

186

5.4

199

5.7

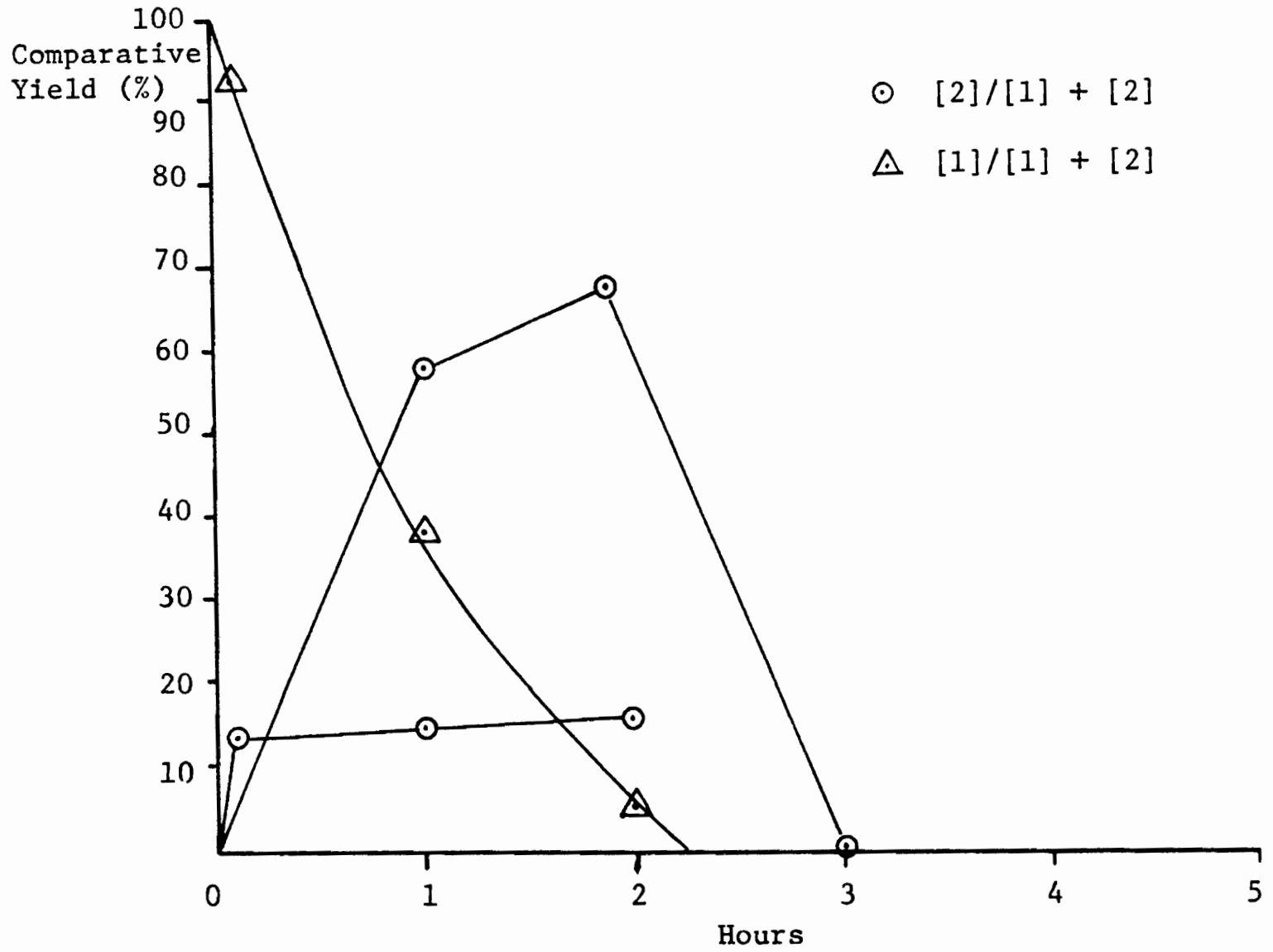

Figure 6. Effect of adding dichloromethane on $\delta$-lactam [2] formation and nitrile oxide [1] disappearance in methanol. Refer to Table IV. 
Photolyses of 0-methyl podocarpinitrile oxide [1] in methanolhexafluorobenzene yielded $\delta$-lactam [2] which appeared to decompose along with the starting material.

TABLE VIII

PHOTOLYSES IN METHANOL-HEXAFLUOROBENZENE

REACTION mg NITRILE OXIDE [1] HOURS

1

2
153

197
5.5

1.5

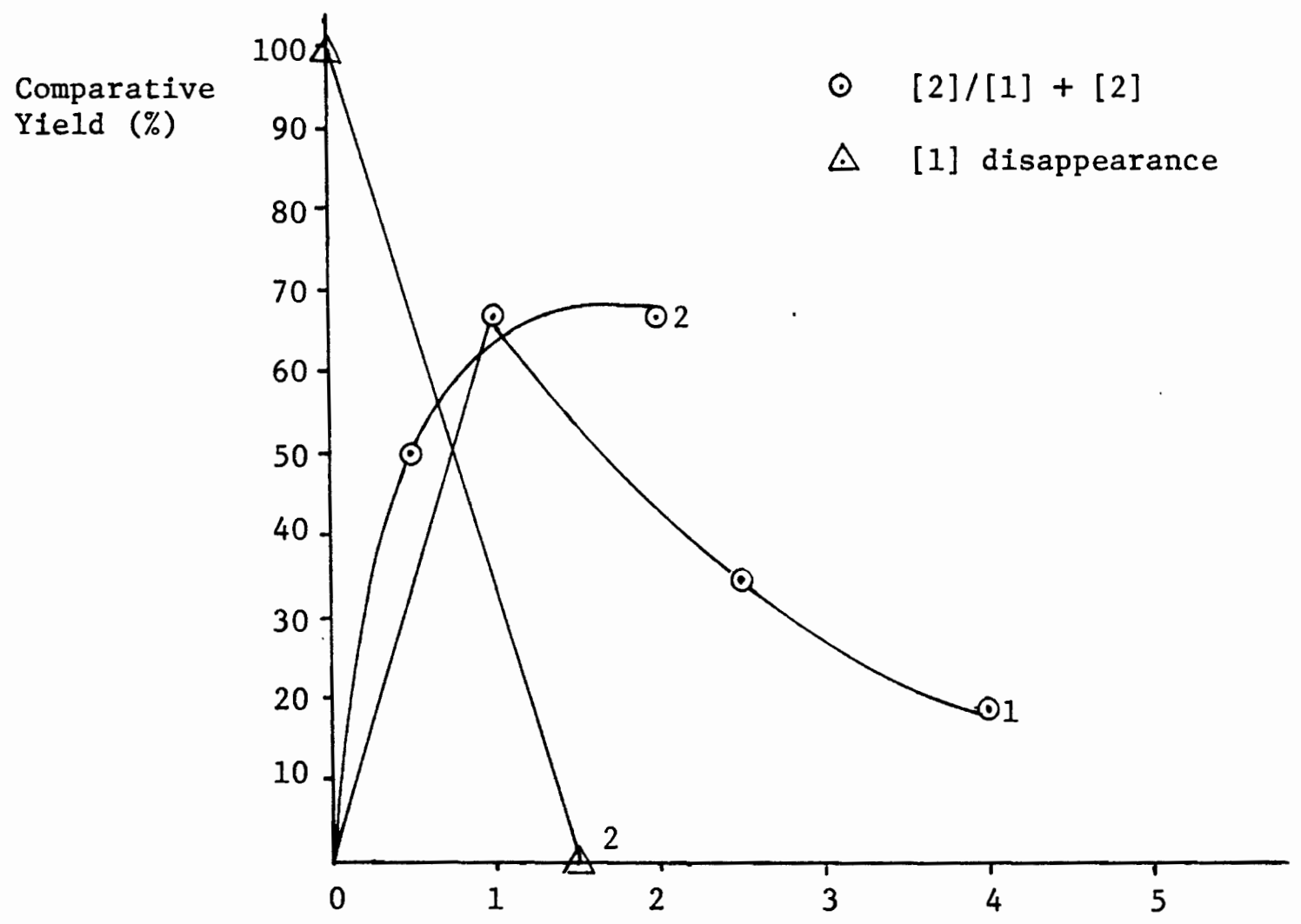

Figure 7. Effect of adding hexafluorobenzene on $\delta$-lactam [2] formation in methanol. (Refer to Table VIII.) 
3. Comparison of Methanol and Hexane. One photolysis was run in methanol and one in hexane under identical conditions and workup to determine the solvent of choice. The products of each were isolated by silica gel column chromatography (figure 8). However, formidable problems were encountered which overwhelmed any difference in yield. Hexane is preferred for the ease of isolating the product.

4. Thermal study. 0-methyl podocarpinitrile oxide [1] was refluxed in hexane and methanol for six hours to study its thermal stability. Analysis by high pressure liquid chromatography and infrared indicated no reaction. 


\section{S-LACTAM [2] PHOTOLYSES}

Photolyses of $\delta$-lactam [2] were performed under the same conditions as for nitrile oxide [1] (in hexane, hexane-dichloromethane methanol, methanol-dichloromethane, and methanol-hexafluorobenzene) for periods of two to four hours. The photolyses were monitored by high pressure liquid chromatography. The $\delta$-lactam appeared relatively stable only in hexane, although a decrease was observed even in this case. The amount of lactam decreased with time in the other solvents and new peaks appeared in the chromatograms.

\section{TABLE IX}

SUMMARY OF $\delta$-IACTAM PHOTOLYSES

\begin{tabular}{|c|c|c|c|}
\hline REACTION & SOLVENT & $\delta$-LACTAM [2] & DESCRIPTION OF PRODUCT \\
\hline 1 & hexane & 49 & light brown oil + solid \\
\hline 2 & hexane $-\mathrm{CH}_{2} \mathrm{Cl}_{2}$ & 40 & brown oil + solid \\
\hline 3 & methanol & 42 & brown oil + solid \\
\hline 4 & methanol- $-\mathrm{CH}_{2} \mathrm{Cl}_{2}$ & 42 & brown oil \\
\hline 5 & methanol- $\mathrm{F}_{6} \mathrm{C}_{6}$ & 49 & dark brown oil \\
\hline
\end{tabular}

\section{ANISOLE PHOTOLYSES}

Anisole was irradiated as a model for the $\delta$-lactam [2] photolyses under the' same conditions (hexane, hexane-dichloromethane, methanol, methanol-dichloromethane), as shown below.

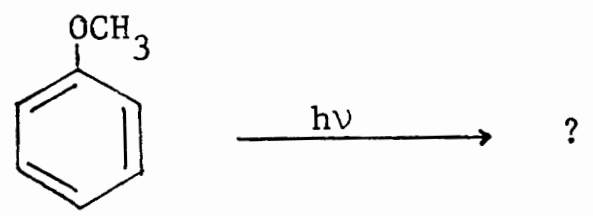


When the photolyses were carried out in the presence of dichloromethane, the cold finger was covered with a thin brown film, which could not be removed by rinsing with methanol. The irradiated solutions with dichloromethane, after concentration, were a pale yellow. High pressure liquid chromatography analysis indicated no reaction. The infrared spectrum showed no extraneous peaks and was virtually identical with the spectrum of anisole. Therefore, it was concluded that the anisole part of the $\delta$-lactam [2] probably was not the site of reaction in the cases in which the $\delta$-lactam [2] disappeared. 
CHAPTER V

\section{EXPERIMENTAL}

Podocarpic acid was obtained from Pfaltz and Bauer, Inc. Lead tetraacetate was obtained from Matheson, Coleman, and Bell. All solvents except ethyl ether, were purified by simple distillation (hexane, methanol, ethyl acetate, dichloromethane, anisole). Analytical reagent grade ethyl ether and anhydrous ethyl ether were used. Methanol used for high pressure liquid chromatography was obtained from Baker (HPLC Reagent grade) and filtered through $0.5 \mathrm{\mu m}$ teflon filters by Millipore. Photolyses were carried out in a Pyrex cell with a quartz cold finger (see Figure 2) and Pyrex, Corex or Vycor filters by Hanovia (see Figure 4). Solvents for photolyses were deoxygenated by flushing the solution with nitrogen with heat and stirring for thirty minutes. The photolyses were irradiated with a Hanovia mercury lamp of 450 or 100 watts. Melting points were determined with a Buchi Schmeltzpunktbestimmungsapparat in open and sealed capillary tubes and are uncorrected. IR spectra were obtained with a Perkin-Elmer Model 467 and calibrated (polystyrene). ${ }^{I_{H}}$ NMR were recorded with a Varian 390, internally locked to the hydrogen frequency of tetramethylsilane (TMS). Chemical shifts were recorded as $\delta(\mathrm{ppm})$ relative to TMS. Thin layer chromatography utilized precoated silica gel Bakerflex 1BF and Baker F254 plates. Column chromatography was performed with silica gel Woelm type 206 by ICN 
Pharmaceuticals in a column of $25 \times 1000 \mathrm{~mm}$ by Altex and using a pump by Fluid Metering, Inc., model R479 (see Figure 8). High pressure liquid chromatography (HPLC) were performed with a Waters Associate Model 444, using a $\mu \mathrm{C}_{18}$ reverse phase $\mu$ Porasil column, a $254 \mathrm{~nm}$ detector, and 60:40 methanol:water as eluent at a flow rate of 3 $\mathrm{mL} / \mathrm{min}$. The $\delta$-lactam was identified by direct comparison with an authentic sample ${ }^{30}$ (IR, TLC, HPLC, NMR, mp).

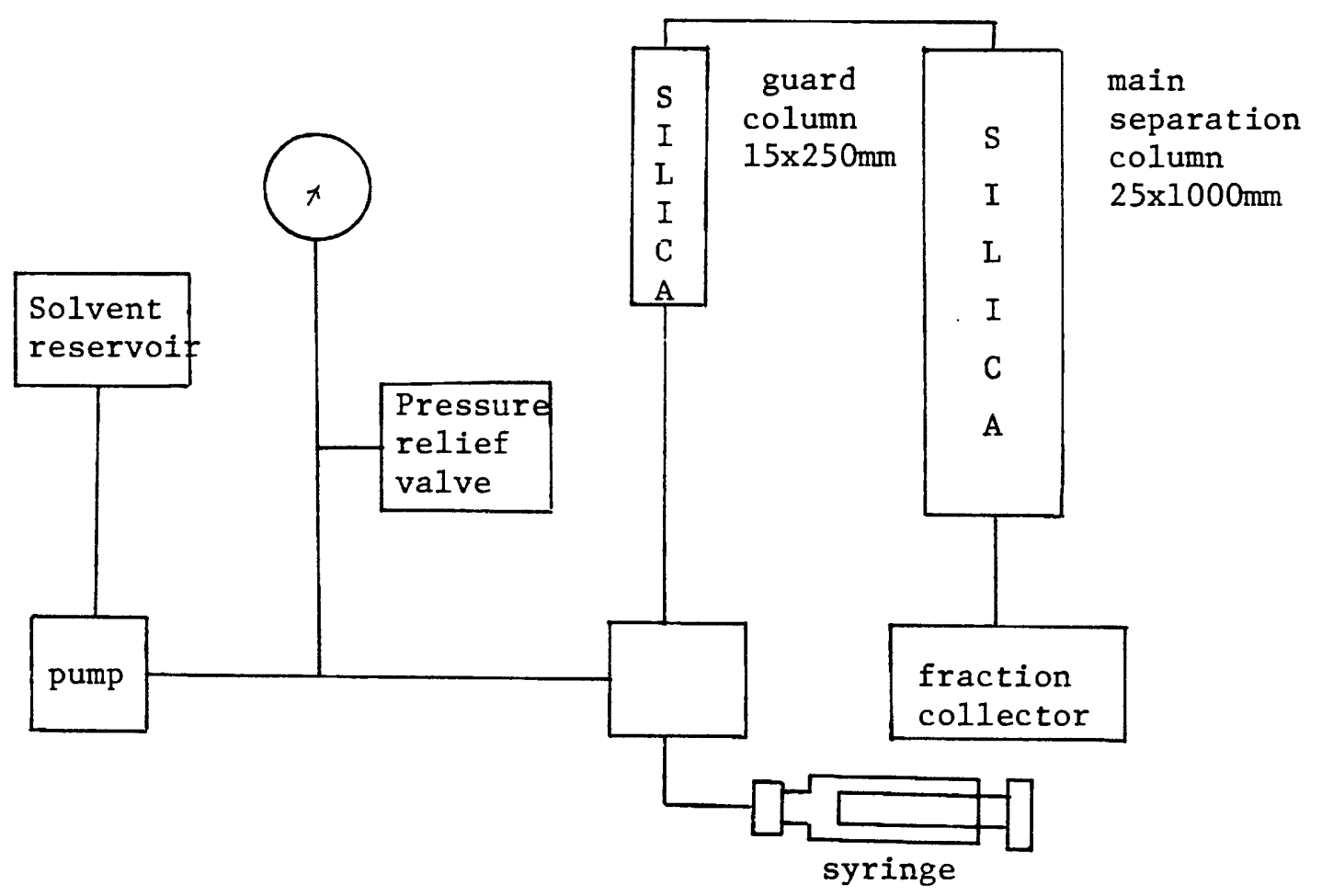

Figure 8. Preparative liquid chromatography schematic diagram. 
TYPICAL PROCEDURE FOR THE PREPARATION OF O-METHYL PODOCARPINITRILE OXIDE [1]

Step 1. Preparation of Methyl 0-methyl podocarpate ${ }^{(8,31)}[21]$

Podocarpic acid [8](9.3 $\mathrm{g}, 0.018 \mathrm{~mole})$ was dissolved in a solution of sodium hydroxide $(2.5 \mathrm{~g}), 15 \mathrm{~mL}$ methanol, and $15 \mathrm{~mL}$ water. Dimethylsulfate $(7.1 \mathrm{~mL}, 0.073 \mathrm{~mole})$ was added dropwise with stirring. A beige precipitate resulted. The mixture was refluxed for fifteen minutes and stirred overnight. The precipitate was isolated by filtration and washed with water. The filtrate was concentrated under vacuum and additional solid was recovered. Recrystallization of the combined crude solids from hexane gave $8.0 \mathrm{~g}$ (78\%), mp $126-128^{\circ} \mathrm{C}$ (1it. $\left.127-128,{ }^{8} 128-129,,^{31} 129-134^{32}\right)$, IR ( $\left.\mathrm{KBr}\right) 1710\left(\mathrm{COOCH}_{3}\right)$, NMR $\left(\mathrm{CCl}_{4}\right) \delta 0.96\left(\mathrm{~s}, \mathrm{CH}_{3}-18\right), 1.22\left(\mathrm{~s}, \mathrm{CH}_{3}-20\right), 3.58$ (s, $\left.\mathrm{PhOCH}_{3}\right)$, $3.66\left(\mathrm{~s}, \mathrm{COOCH}_{3}\right)$ 6.4-6.8 (m, 3ArH), HPLC (Table XVII); and $1.4 \mathrm{~g}$ (13\%) mp $139-140^{\circ} \mathrm{C}$ (0-methyl podocarpic acid 1it. mp 154-156 ${ }^{29,31}$ ); IR (KBr) 3100-2700 (OH stretch), 1690 ( $\mathrm{COOH}$ dimer), 920 (OH out of plane); and HPLC (Table XVII).

The second product was treated with additional dimethyl sulfate under the same conditions. Recrystallization resulted in $0.85 \mathrm{~g}$ (60\%); mp 126-128; IR ( KBr) $1710\left(\mathrm{COOOCH}_{3}\right)$. Net recovered methyl 0-methyl podocarpate was $8.85 \mathrm{~g}(86 \%)$. 
TABLE X

SUMMARY OF METHYL O-METHYL PODOCARPATE [21] SYNTHESES

\begin{tabular}{ccccc} 
REACTION & gm ACID [20] & gm ESTER [21] & \% YIELD & mp \\
\hline 1 & 11.0 & 6.9 & 60 & $126-127$ \\
2 & 11.0 & 9.6 & 86 & $126-128$ \\
3 & 30.0 & 13.0 & 40 & $126-127$ \\
4 & 5.0 & 4.5 & 83 & $126-127$ \\
5 & 4.0 & 3.4 & 82 & - \\
6 & 5.0 & 4.5 & 93 & $117-127$ \\
7 & 4.2 & 3.7 & 82 & $117-125$ \\
8 & 8.9 & 7.3 & 87 & $126-127$
\end{tabular}

Step 2. Preparation of O-methyl podocarpinol $8,33,34$ [22]

Methyl 0-methyl podocarpate [21] $(4.20 \mathrm{~g}, 0.014 \mathrm{~mole})$ in $20 \mathrm{~mL}$ dichloromethane (or ethyl ether) was added slowly to a mixture of lithium aluminum hydride $(2.00 \mathrm{~g}, 0.050$ mole $)$ and $40 \mathrm{~mL}$ anhydrous ethyl ether under a nitrogen atmosphere at room temperature. The resulting mixture was refluxed for twenty-four hours. Unreacted hydride was destroyed with an aqueous sodium hydroxide solution (10\%). The white solid that resulted was filtered and washed with ether. The organic fraction was washed with water and concentrated under vacuum to dryness. Recrystallization of the crude alcohol from hexane gave 3.45 g, $(90 \%) ; \operatorname{mp} 90-91^{\circ} \mathrm{C}$ (1it. $\left.91-92^{8} ; 90-91^{33,34}\right)$; IR $\left(\mathrm{CCl}_{4}\right) 3625$ (OH stretch), 1270 (OH bend); 1040 (CO stretch): NMR $\left(\mathrm{CCl}_{4}\right) \delta 1.00\left(\mathrm{~s}, \mathrm{CH}_{3}-\right.$ 20), $1.26\left(\mathrm{~s}, \mathrm{CH}_{3}-18\right), 3.66\left(\mathrm{~s}, \mathrm{PhOCH}_{3}\right) \mathrm{HPLC}$ (Table X́VII). 
TABLE XI

SUMMARY OF O-METHYL PODOCARPINOL [22] SYNTHESES

\begin{tabular}{ccccc} 
REACTION & gm ESTER [21] & gm ALCOHOL [22] $\%$ YIELD & mp \\
\hline 1 & 2.10 & 1.34 & 77 & $90-91$ \\
2 & 11.13 & 7.00 & 69 & - \\
3 & 10.04 & 2.91 & 27 & $90-91$ \\
4 & 6.02 & 3.64 & 67 & $90-91$ \\
5 & 6.52 & 5.68 & 95 & $90-91$ \\
6 & 7.57 & 6.29 & 91 & $90-91$ \\
7 & 4.11 & 3.41 & 90 & $90-91$ \\
8 & 3.51 & 2.80 & 85 & $90-91$ \\
9 & 9.55 & 7.25 & 83 & $90-91$
\end{tabular}

Step 3. Preparation of 0-methyl podocarpinal [23].

0-methyl podocarpinol [22] (3.60 $\mathrm{g}, 13 \mathrm{mmole}$ ) in $20 \mathrm{~mL}$ dichloromethane was added to a mixture of pyridium chlorochromate ${ }^{28}(4.8 \mathrm{~g}$, 22 mole). Pyridinium chloromate is light sensitive. ${ }^{35}$ The orange colored chromate immediately turned brown. The mixture was stirred for thirty minutes at room temperature. An isopropanol-water mixture $(1: 1 \mathrm{v}: \mathrm{v})$ was added to destroy the unreacted chromate. The resulting slurry was extracted with ether. Organic layers were combined and concentrated to dryness under vacuum. Recrystallization of the crude solid from methanol gave $2.43 \mathrm{~g}$ (69\%), mp $120-121^{\circ} \mathrm{C}$ (1it. $135-136^{29}$, $\left.133-135^{37}, 133-133^{36}\right)$, IR ( $\left.\mathrm{KBr}\right) 2720(\mathrm{H}-\mathrm{C}-\mathrm{C}=0), 1710(\mathrm{C}=0)$; NMR $\left(\mathrm{CCl}_{4}\right)$ $\delta 1.03\left(\mathrm{~s}, \mathrm{CH}_{3}-20\right), 1.06\left(\mathrm{~s}, \mathrm{CH}_{3}-18\right), 3.61$ (s, $\left.\mathrm{PhOCH}_{3}\right), 9.69$ (d, $\mathrm{J}=1.5 \mathrm{~Hz}$, axial $\mathrm{CHO}$ ), (1it. 9.70, (d, J=1.25Hz, $\left.\mathrm{CHO}^{29}\right)$ ); HPLC (Table XVII). 
TABLE XII

SUMMARY OF O-METHYL PODOCARPINAL [23] SYNTHESES

REACTION gm ALCOHOL [22] gm ALDEHYDE [23] $\%$ YIELD mp

$\begin{array}{rrrrc}1 & 0.27 & 0.15 & 57^{\mathrm{a}} & 119-122 \\ 2 & 0.28 & & \mathrm{~b} & - \\ 3 & 0.28 & & \mathrm{~b} & - \\ 4 & 0.41 & & \mathrm{~b} & - \\ 5 & 2.01 & & \mathrm{~b} & - \\ 6 & 2.62 & & \mathrm{~b} & - \\ 7 & 2.74 & 1.81 & 64 & 114-115 \\ 8 & 2.73 & 0.85 & 31 & 119-126 \\ 9 & 2.70 & 1.36 & 51 & 118-124 \\ 10 & 2.10 & 1.06 & 51 & 116-122 \\ 11 & 3.43 & 1.18 & 34 & 117-127 \\ 12 & 3.04 & 2.09 & 69 & 117-127 \\ 13 & 6.55 & 4.08 & 62 & 120-125\end{array}$

\footnotetext{
a Oxidant used was $\mathrm{CrO}_{3}$ and $\mathrm{H}_{2} \mathrm{SO}_{4}$

b Not recrystallized
}

Step 4. Preparation of 0-methyl podocarpinaldoxime ${ }^{8}$ [24]

0-methyl podocarpinal [23] $(2.20 \mathrm{~g}, 8.1 \mathrm{mmole})$ in a solution of $50 \mathrm{~mL}$ ethanol and $80 \mathrm{~mL}$ pyridine, was added to a solution of hydroxylamine hydrochloride $(3.0 \mathrm{~g}, 40 \mathrm{mmole})$ and sodium acetate $(8.2 \mathrm{~g}, 10$ mmole) in $50 \mathrm{~mL}$ water. The solution was refluxed for two hours and concentrated under vacuum. The resulting solid was isolated by filtration and washed with water. Recrystallization of the crude solid from methanol gave $1.91 \mathrm{~g}(82 \%)$, mp $140-141^{\circ} \mathrm{C}$ (lit. $140-141^{8}$ ); IR $\left(\mathrm{CCl}_{4}\right)$ 
3600 and 3100 (broad, $\mathrm{N}-\mathrm{OH}$ stretch); $\mathrm{NMR}\left(\mathrm{CCl}_{4}\right) \delta 1.10\left(\mathrm{~s}, \mathrm{CH}_{3}-20\right), 1.13$ $\left(\mathrm{s}, \mathrm{CH}_{3}-18\right), 3.67\left(\mathrm{~s}, \mathrm{PhOCH}_{3}\right), 7.36(\mathrm{~s}, \mathrm{HC}=\mathrm{N}-\mathrm{OH}$ anti), 8.16（s, $\mathrm{C}=\mathrm{N}-\mathrm{OH}$ syn); HPLC (Table XVII).

TABLE XIII

SUMMARY OF O-METHYL PODOCARPALDOXIME [24] SYNTHESES gm ALDEHYDE [23]

gm ALDOXIME [24] \% YIELD mp

$\begin{array}{clllc}1 & - & 0.03 & 6^{\mathrm{a}} & - \\ 2 & 0.22^{\mathrm{b}} & 0.14 & 60^{\mathrm{a}} & - \\ 3 & -- & 0.40 & 90^{\mathrm{a}} & 139-140 \\ 4 & 2.0^{\mathrm{b}} & 1.9 & 80^{\mathrm{a}} & 140-141 \\ 5 & 2.6^{\mathrm{b}} & 1.2 & 56^{\mathrm{a}} & 140-141 \\ 6 & 0.10 & 0.05 & 50^{\mathrm{a}} & 141-142 \\ 7 & 1.62 & 1.26 & 73 & 140-142 \\ 8 & 2.22 & 2.16 & 92 & 140-141 \\ 9 & 1.88 & 1.63 & 69 & 140-141 \\ 10 & 2.21 & 1.95 & 82 & 140-141 \\ 11 & 4.01 & 3.63 & 87 & 141-142\end{array}$

\footnotetext{
a Overall yield from alcohol to aldoxime

b crude weight
}

Step 5. Preparation of 0-methyl podocarpinitrile oxide ${ }^{8}, 11$ [1]

0-methyl podocarpaldoxime (500 $\mathrm{mg}, 1.7$ mmole) was dissolved in $25 \mathrm{~mL}$ dichloromethane. Lead tetraacetate ( $2.25 \mathrm{~g}, 5.1 \mathrm{mmole})$ was added at room temperature. The mixture turned an opaque yellow and was stirred for five minutes. Unreacted lead tetraacetate was hydrolyzed with $25 \mathrm{~mL}$ ice water, resulting in a brown precipitate. The layers 
were separated and the aqueous layer was extracted with ethyl ether. The combined organic fractions were concentrated under vacuum to dryness. The crude solid was dissolved in ethyl ether and the solution was washed with $50 \mathrm{~mL}$ saturated sodium carbonate, $50 \mathrm{~mL} 40 \%$ ammonium sulfate, and $50 \mathrm{~mL}$ water. The solvent was removed and recrystallization of the crude solid from methanol gave $430 \mathrm{mg}(86 \%)$; $\mathrm{mp} 129-130^{\circ} \mathrm{C}$

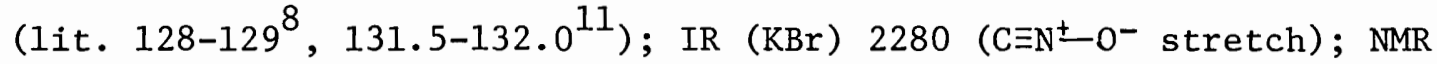
$\left(\mathrm{CCl}_{4}\right) \delta 1.03\left(\mathrm{~s}, \mathrm{CH}_{3}-20\right), 1.47\left(\mathrm{~s}, \mathrm{CH}_{3}-18\right) 3.70$ (s, $\left.\mathrm{PhOCH}_{3}\right), 6.4-6.8$ (m, $\left.3 \mathrm{ArH}) ; \mathrm{UV} \mathrm{MeOH}_{\max } 279, \varepsilon_{279} 600 ; \varepsilon_{254} 40\right) ; \mathrm{HPLC}$ (Table XVII).

TABLE XIV

SUMMARY OF O-METHYL PODOCARPINITRILE OXIDE [1] SYNTHESES REACTION mg OXIM

1

1

2

3

4

5

6

7

8

9

10

11

12

13

14

493

634

500

526

386

334

369

475

452

491

95

54

$129-130$

54

$129-130$

71

129-130 
TABLE XIV (cont: )

$\begin{array}{rrrrr}15 & 724 & 358 & 50 & 125-130 \\ 16 & 542 & 367 & 68 & 125-130 \\ 17 & 3570 & 3090 & 87 & 129-130\end{array}$

TYPICAL PROCEDURES FOR THE PHOTOLYSIS OF

O-METHYL PODOCARPINITRILE OXIDE [1]

1. Hexane. $^{8}$ 0-methyl podocarpinitrile oxide [1] (200 mg, 7.0 mnole) was dissolved in $300 \mathrm{~mL}$ hexane in the photolysis cell (see Figure 2). The solution was irradiated with a 450 watt mercury lamp for two hours. A beige precipitate formed on the walls and in the solution. It was collected by filtration. The solid that remained on the walls was dissolved in methanol and combined with the hexane filtrate. The resulting mixture was concentrated under vacuum to recover additional solid. Lactam remaining in the concentrated mother liquors was isolated by column chromatography, eluting with ethyl acetate. Recrystallization of the crude $\delta$-lactam from absolute ethanol gave $45 \mathrm{mg}$ (22\%) mp (sealed tube) $270-272^{\circ} \mathrm{C}$, (1it. mp $\left.272-274^{\circ}\right)^{8}$; IR (KBr) 3340-3240 (m, NH), $1660(\mathrm{C}=0), 1615$ (aromatic), $1270(\mathrm{C}-\mathrm{O}-\mathrm{C})$, NMR $\left(\mathrm{CCl}_{4}\right) \delta 1.23\left(\mathrm{~s}, \mathrm{CH}_{3}-20\right), 2.75\left(\mathrm{~s}, \mathrm{PhOCH}_{3}\right), 5.96(\mathrm{~s},-\mathrm{CONH}-), 6.53(\mathrm{~d}$, $\mathrm{J}=0.85, \operatorname{ArH}-11$ ), 6.74 (dd, J=0.85, 2.4, ArH-14), 6.95 (d, J=2.4, ArH-13); HPLC. (Table XVII); UV $\mathrm{MeOH}_{\text {max }}\left(\lambda_{\text {ma }} 279, \varepsilon_{279} 1200, \varepsilon_{258} 90\right)$. (See Table III.)

2. Hexane-dichloromethane. 0-methyl podocarpinitrile oxide [1] (200 mg, 0.7 mmole) was dissolved in $300 \mathrm{~mL}$ hexane in the photolysis cell. Dichloromethane ( $45 \mu \mathrm{L}, 0.7$ mmole; or $450 \mu \mathrm{L}, 7.0$ mmole) was added after cooling. The solution was irradiated with a 450 watt 
mercury lamp for 2.8 to 8.0 hours with stirring. The dark brown precipitate on the walls and in the yellow solution was collected by filtration $(88 \mathrm{mg}), \mathrm{mp} 170^{\circ} \mathrm{C}$. The solid remaining on the walls was dissolved in methanol and combined with the filtrate. The filtrate was concentrated to a brown oil and analyzed by IR and HPLC. (See Table IV.)

3. Methanol. 0-methyl podocarpinitrile oxide [1] (200 mg, 0.7 mmole) was dissolved in $300 \mathrm{~mL}$ methanol. The solution was irradiated with a 450 watt mercury lamp or a 100 watt mercury lamp (Table V, Figure 3), with or without a filter (Pyrex, Corex, Vycor) (Table VI, Figure 4). Samples taken at hourly intervals were analyzed by HPLC. HPLC results were determined by measuring the area of the peaks corresponding to $\delta$-lactam [2] and nitrile oxide [1]. A comparative yield was calculated by taking a ratio of the area of $\delta$-lactam [2] to the sum of the areas of $\delta$-lactam [2] and nitrile oxide [1].

The solution, after photolysis, was concentrated to approximately $10 \mathrm{~mL}$ and analyzed by IR and HPLC.

4. Methanol-dichloromethane. 0-methyl podocarpinitrile oxide [1] (200 $\mathrm{mg}, 0.70 \mathrm{mmole}$ ) was dissolved in $300 \mathrm{~mL}$ methanol in the photolysis cell. Dichloromethane ( $450 \mu \mathrm{L}, 0.70$ mmole) was added. The solution was irradiated with a 450 watt mercury lamp for 5 to 6 hours. The reaction was monitored by analyzing samples taken at hourly intervals with HPLC. The solution was concentrated under vacuum to a brown oil of approximately $20 \mathrm{~mL}$. (See Table VII and Figure 6.)

5. Methanol-hexafluorobenzene. O-methyl podocarpinitrile oxide [1] (200 mg, $0.70 \mathrm{mmole}$ ) was dissolved in $300 \mathrm{~mL}$ of methanol in the photolysis cell. Hexafluorobenzene $(81 \mu \mathrm{L}, 0.70 \mathrm{mmole})$ was added. The 
solution was concentrated under vacuum to $5 \mathrm{~mL}$ of a dark brown oil. (See Table VIII and Figure 8.)

\section{THERMAL STABILITY STUDY OF}

O-METHYL PODOCARPINITRILE OXIDE [1]

1. Hexane. 0-methyl podocarpinitrile oxide [1] (20 mg, 0.07 mmole) was refluxed in $30 \mathrm{~mL}$ hexane for six hours. No reaction was indicated by IR and HPLC analyses.

2. Methanol. 0-methyl podocarpinitrile oxide (20 mg, 0.07 mmole) was refluxed in $30 \mathrm{~mL}$ methanol for six hours. No reaction was indicated by IR and HPLC analysis.

\section{PHOTOLYSIS OF $\delta$-LACTAM [2]}

1. Hexane. $\delta$-lactam $(49 \mathrm{mg}, 0.17$ mole) was added to $300 \mathrm{~mL}$ hexane. The mixture was irradiated with a 450 watt mercury lamp as before, for 3.5 hours. Samples taken at approximate hourly intervals were analyzed with HPLC. The mixture was concentrated to $25 \mathrm{~mL}$ and analyzed by IR and HPLC. (See Table IX.)

2. Hexane-dichloromethane. $\delta$-lactam (40 mg, $0.14 \mathrm{mmole}$ ) and dichloromethane ( $45 \mu \mathrm{L}, 0.7$ mmole) were added to $300 \mathrm{~mL}$ hexane as before. The mixture was irradiated with a 450 watt mercury lamp for 3.5 hours. Samples taken at hourly intervals were analysed by HPLC. The mixture was concentrated to $10 \mathrm{~mL}$ (oil and some solid) and analyzed by IR and HPLC. (See Table IX.)

3. Methanol. $\delta$-lactam (42 mg, 0.15 mole) was dissolved in 300 ml methanol as before. The mixture was irradiated with a 450 watt mercury lamp for 3.4 hours. Samples were taken at half hour intervals 
and analyzed by IR and HPLC. The solution was concentrated to $3 \mathrm{~mL}$. (See Table IX.)

4. Methanol-dichloromethane. $\delta$-lactam (49 mg, 0.17 mmole) was dissolved in $300 \mathrm{~mL}$ methanol as before. Dichloromethane ( $45 \mu \mathrm{L}, 0.7$ mmole) was added. The solution was irradiated with a 450 watt mercury lamp for two hours. Samples taken at half hour intervals were analyzed by HPLC. The solution was concentrated to $10 \mathrm{~mL}$ and analyzed by IR and HPLC. (See Figure IX.)

5. Methanol-hexafluorobenzene. $\delta$-lactam (40 mg, 0.17 mmole) was dissolved in $300 \mathrm{~mL}$ methanol as before. Hexafluorobenzene ( $80 \mu \mathrm{L}$, 0.7 mmole) was added. The solution was irradiated with a 450 watt mercury lamp for 3.8 hours. Samples taken at half hour intervals were analyzed by HPLC. The solution was concentrated to $3 \mathrm{~mL}$ of an oil and analyzed by IR and HPLC. (See Figure IX.)

\section{ANISOLE PHOTOLYSES}

1. Hexane. Anisole $(7.6 \mathrm{~mL}, 0.07$ mole) was added to $300 \mathrm{~mL}$ hexane. The solution was irradiated with a 450 watt mercury lamp for 2.5 hours. The solution was concentrated by fractional distillation. Samples of the initial, final and concentrated solutions were analyzed by HPLC. The concentrate was analyzed by IR. (See page 27.)

2. Hexane-dichloromethane. Anisole (7.6 mL, 0.07 mole) and dichloromethane ( $45 \mu \mathrm{L}, 0.7 \mathrm{mmole}$ ) were added to $400 \mathrm{~mL}$ methanol. The solution was irradiated with a 450 watt mercury lamp for 2.5 hours. The solution was concentrated by fractional distillation. Samples of the initial, final, and concentrated solutions were analyzed by HPLC. The concentrate was analyzed by IR. (See page 27.) 
TABLE XV

SUMMARY OF ANISOLE PHOTOLYSES IN HEXANE DICHLOROMETHANE

\begin{tabular}{cccc} 
REACTION & mL ANISOLE & $\mathrm{mL} \mathrm{CH}_{2} \mathrm{Cl}_{2}$ & $\mathrm{CH}_{2} \mathrm{Cl}_{2}$ :ANISOLE \\
\hline 1 & 7.6 & 0.045 & $1: 100$ \\
2 & 2.5 & 1.5 & $1: 1$
\end{tabular}

3. Methanol. Anisole $(7.6 \mathrm{~mL}, 0.07$ mole) was added to $300 \mathrm{~mL}$ methanol. The solution was irradiated with a 450 watt mercury lamp for 2.5 hours. The solution was concentrated by fractional distillation. Samples of the initial, final and concentrated solutions were analyzed by HPLC. (See page 27.)

4. Methanol-dichloromethane. Anisole (7.6 mL, $0.07 \mathrm{~mole})$ and dichloromethane $(450 \mu \mathrm{L}, 0.007$ mole) were added to $300 \mathrm{~mL}$ methanol. The solution was irradiated with a 450 watt mercury lamp for 2.5 hours. The solution was concentrated by fractional distillation to a pale yellow solution. Samples of the initial, final and concentrated solutions were analyzed by HPLC. (See page 27.)

\section{TABLE XVI}

SUMMARY OF ANISOLE PHOTOLYSES IN

METHANOL-DICHLOROMETHANE

\begin{tabular}{cccc} 
REACTION & $\mathrm{mL}$ ANISOLE & $\mathrm{mL} \mathrm{CH} \mathrm{Cl}_{2}$ & $\mathrm{CH}_{2} \mathrm{Cl}_{2}$ :ANISOLE \\
\hline 1 & 7.6 & 0.45 & $1: 10$ \\
2 & 2.5 & 1.5 & $1: 1$
\end{tabular}


TABLE XVII

HIGH PRESSURE LIQUID CHROMATOGRAPHY RESULTS

OF REACTION PRODUCTS

\begin{tabular}{lccc} 
COMPOUND & $\begin{array}{c}\text { RETENTION } \\
\text { TIME (MIN.) }\end{array}$ & $\begin{array}{c}\text { PRESSURE } \\
\text { (psi) }\end{array}$ & $\begin{array}{c}\text { CAPACITY } \\
\text { RATIO }\end{array}$ \\
\cline { 2 - 3 } [21] & 7.1 & 4000 & 27 \\
alcohol [22] & 9.5 & 5000 & 37 \\
aldehyde [23] & 11.0 & 4200 & 43 \\
aldoxime, syn & 10.1 & 4200 & 39 \\
aldoxime, anti [24] & 11.3 & 4200 & 44 \\
nitrile oxide [1] & 7.2 & 4400 & 28 \\
d-lactam [2] & 5.1 & 4100 & 19
\end{tabular}


CHAPTER VI

CONCLUSIONS

0-methyl podocarpinitrile oxide [1] was synthesized from podocarpic acid [20] following Just and Zehetner's procedure ${ }^{8}$, except for the use of pyridinium chlorochromate ${ }^{28}$ to prepare 0 -methyl podocarpinal [23]. The reaction sequence involved methylation of podocarpic acid [20] to methyl 0-methyl podocarpate [2]], reduction of ester [21] to 0-methyl podocarpinol [22], oxidation of alcohol [22] to 0-methyl podocarpinal [23], conversion to 0-methyl podocarpaldoxime [24], and then oxidation to 0-methyl podocarpinitrile oxide [1] in an overall yield of $41 \%$. (Figure 1. )

The irradiation of 0-methyl podocarpinitrile oxide [1] in hexane was studied to reproduce Just and Zehetner's results ${ }^{1,8}$ (25\% $\delta-1$ actam [2]). Yields of $50-60 \%$ crude $\delta$-lactam [2] were obtained. Rinsing the cold finger periodically to remove the film of $\delta$-lactam [2] proved important in increasing the yield to $85-90 \%$. (although without complete reproducibility). The other major variation from the reported work regards the Rayonet UV source used by Just and Zehetner versus a high * pressure Hanovia 450 watt mercury lamp used in this work.

The proposed intermediate in this reaction is a singlet alkanoylnitrene [18]. Carbonylnitrenes have been shown to be stabilized through interaction of lone pair electrons. Singlet alkanoylnitrenes are believed to be stabilized by addition of dichloromethane and 
singlet alkoxycarbonylnitrenes by addition of hexafluorobenzene to the reaction.

The following photolysis conditions were studied to optimize the yield of $\delta$-lactam [2]: solvent (methanol, hexane), mercury lamp wattage (100w, 450W), filters (Vycor, Corex, Pyrex), and additives (dichloromethane, hexafluorobenzene).

Hexane was chosen as the photolysis solvent due to the ease of isolating $\delta$-lactam [2] as it is insoluble. Methanol is useful for monitoring the progress of the photolysis with HPLC, because $\delta$-lactam [2] is soluble in this solvent.

The 450 watt mercury lamp gave higher comparative yields of

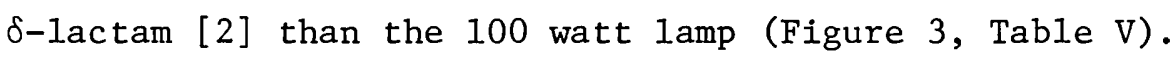

Photolysis with filters (Figure 5) showed that the highest comparative yield of $\delta$-lactam [2] was obtained without filters (Table VI, Figure 4).

Photolysis in the presence of additives in molar ratios to nitrile oxide of $1: 1$ and $1: 10$ (RCNO:additive) did not increase the yield of $\delta$-lactam. In fact, it appeared that either nitrile oxide [1] and/or $\delta$-lactam [2] was being decomposed (Tables IV, VII, and VIII, Figures 6 and 7).

Photolyses of $\delta$-lactam [2], under the conditions in which it was formed, indicated that it was relatively stable only in hexane. It disappeared under the other conditions (Table IX).

Anisole was photolyzed to see if the anisole ring of $\delta$-lactam [2] was the part that caused the decompositon. No major reaction was evident under the same conditions as that of the $\delta$-lactam [2] photolyses. 
There are unanswered questions in this area of $\delta$-1actam synthesis. Dinitrobenzene ${ }^{21}$ and $1,4-$ dioxane $^{37}$ are believed to stabilize singlet alkoxycarbonylnitrenes, increasing the yield of insertion products. Photolysis of 0-methyl podocarpinitrile oxide [1] in the presence of these additives might result in a higher yield of $\delta$-lactam [2].

Mesitonitrile has been photolyzed to a $\delta$-lactam. ${ }^{1}$ The effect of adding dinitrobenzene, 1,4-dioxane, dichloromethane, or hexafluorobenzene to the photolysis could be studied. The results from the above studies would add to the knowledge of the nature of the reaction and the intermediate.<smiles>Cc1cc(C)c(C#N)c(C)c1</smiles>

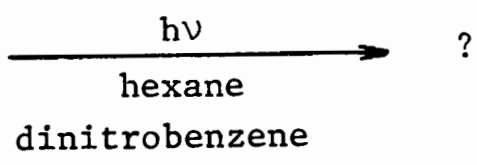

A possible application of this study is the development of a method to prepare an oxo-morphan ring [26]. Exploiting the advances of this work, the use of the nitrile oxide [25], if it is stable with 
respect to dimerization, could be suggested. The $\delta$-lactam [26] might then be prepared using the optimum conditions determined by this research.

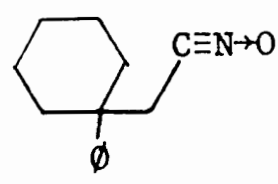

[25]

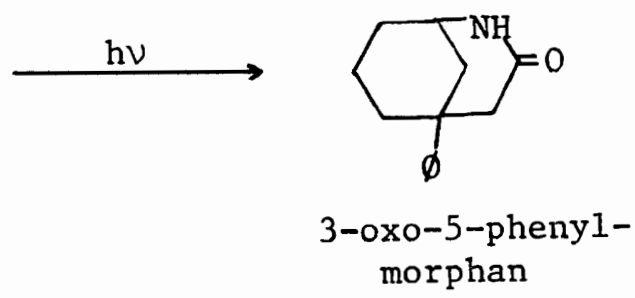

[26] 
1. Just, G. and Zehetner, W., Tetrahedron Letters, 3389 (1967).

2. Werner, A. and Buss, H., Berichte 27, 2193 (1894).

3. Wieland, H., Berichte 61, 1041 (1907).

4. Pauling, I. and Hendricks, S. B., J. Am. Chem. Soc. 48, 641 (1926).

5. Quilico, A. and Sperani, G., Gazz. Chim. Ital. 76, 148 (1946).

6. Huisgen, R., Proc. Chem. Soc. 357 (1961).

7. Grundmann, C. and Dean, J. M., Angew. Chem. 76, 682 (1964).

8. Zehetner, W., "Photolysis of Nitrile Oxides; Reactions of Nitroso Olefins," McGill University, Montreal, (1970), (Ph.D. thesis).

9. Grundmann, C. and Dean, J. M., J. Org. Chem. 30, 2809 (1963).

10. Grundmann, C. and Richter, R., J. Org. Chem. 33, 476 (1968).

11. Just, G. and Dahl, K., Tetrahedron 24, 5251 (1968).

12. Grundmann, C. and Grunanger, P., "The Nitrile Oxides, Versatile Tools of Theoretical and Preparative Chemistry," SpringerVerlag, Berlin, 1971, pp. 46-47.

13. Ibid, p. 65 .

14. ApSimon, J. W. and Edwards, O. E., Can. J. Chem. 40, 896 (1962).

15. Ske11, P. S. and Woodworth, R. C., J. Am. Chem. Soc. 78, 4496 (1956).

16. Yamada, S. and Terashima, S., Chem. Comm., 511 (1969).

17. Lwowski, W. and Linke, J., Justus Liebigs Annalen der Chemie, 8 (1977).

18. Gleiter, R. and Hoffman, R., Tetrahedron 24, 5899 (1968).

19. Lwowski, W., J. Am. Chem. Soc. 87, 5496 (1965).

20. Lwowski, W., J. Am. Chem. Soc. 87, 5491 (1965).

21. Breslow, D. S. and Edwards, E. I., Tetrahedron Letters, 2123 (1967). 
References (cont.)

22. Breslow, D. S. and Edwards, E. I., Tetrahedron Letters, 2041 (1972).

23. Felt, G. R., Linke, S., and Lwowski, W., Tetrahedron Letters, 2937 (1972).

24. Belloli, R. C., Whitehead, M. A., Wollenberg, R. H., and LaBahn, V. A., J. Org. Chem. 39, 2128 (1974).

25. Belloli, R. C. and LaBahn, V. A., J. Org. Chem. 40, 1972 (1975).

26. Takeuchi, H., Murata, N., Nakagawa, Y., Tsuchida, T., and

Koyama, K., J. Chem. Soc. Perkin II, 80 (1977).

27. Alewood, P. F., Kazmaier, P. M., and Rauk, A., J. Am. Chem. Soc. $\underline{95}, 5466$ (1973).

28. Corey, E. I. and Suggs, J. W., Tetrahedron Letters, 2647 (1975).

29. Aranda, G., Bernassau, J., Fetizon, M., J. Org. Chem. 42, 4256 (1977).

30. An authentic sample of $\delta$-lactam [2] was received from Dr. O. E. Edwards of the National Research Council of Canada.

31. Sherwood, I. R. and Short, W. F., J. Chem. Soc., 1006 (1938).

32. Welch, S. C., Hagan, C. P., Kim, J. H., and Chu, P. S., J. Org. Chem. 42, 2879 (1977).

33. Campbe11, W. P. and Todd, D., J. Am. Chem. Soc. 64, 928 (1942).

34. Zeiss, H. H., Slimowicz, C. E., and Pasternale, V. Z., J. Am. Chem. Soc. 70, 1981 (1948).

35. Personal communication with Dr. Arleigh Dodson, Lewis \& Clark Coll.

36. Aranda, G. and Fétizon, M., Synth, 330 (1975).

37. Takeuchi, H., Nishigamo, T., Mitani, M., Tsuchida, T., Koyama, K., Perkin II, 839 (1979).

38. Kuehne, M. E. and Horne, D. A., J. Org. Chem. 40, 1287 (1975).

39. Hasegawa, T., Aoyamo, H., and Omote, Y., J. Chem. Soc. Perkin I, 2034 (1976).

40. Döpp, D., Chem. Comm., 1284 (1968).

41. Schäfer, J., Justus Liebigs Annalen der Chemie 729, 234 (1969). 
References (cont.)

42. Jagt, J. C. and van Leusen, A. M., J. Org. Chem. 39, 564 (1974).

43. Kasahara, A. and Saito, T., Chem. and Ind., 745 (1975).

44. Pellegata, R., Pinza, M. and Pitteri, G., Synth, 614 (1978). 
APPLICATIONS OF NITRILE OXIDE 1,3-DIPOLAR CYCLOADDITION

The following are some general equations illustrating the applications of nitrile oxide 1,3-dipolar cycloaddition.

1. 4,5-dihydro-1,2-oxazoles

$$
\begin{aligned}
& \mathrm{R}^{1}-\mathrm{C}=\mathrm{N} \rightarrow \mathrm{O}+\overbrace{\mathrm{R}^{3}}^{\mathrm{R}^{2}} \rightarrow \overbrace{\mathrm{N}_{0}}^{\mathrm{R}^{4}} \overbrace{\mathrm{R}^{5}}^{\mathrm{R}^{1}} \\
& \mathrm{R}^{1}-\mathrm{C} \equiv \mathrm{N} \rightarrow \mathrm{O}+\mathrm{R}^{2}-\mathrm{C} \equiv \mathrm{C}-\mathrm{R}^{3} \rightarrow \mathrm{N}_{0} \rightarrow \mathrm{R}^{3}
\end{aligned}
$$

2. 1,3,4-dioxazoles

$$
\mathrm{R}^{1}-\mathrm{C} \equiv \mathrm{N} \rightarrow 0+\underbrace{\stackrel{0}{\|}{ }_{\mathrm{R}}^{3}}_{\mathrm{R}^{2}} \rightarrow \sum_{0}^{\mathrm{R}} X_{\mathrm{R}^{3}}^{\mathrm{R}^{2}}
$$

3. 1,2,5-oxadiazole (furazans)

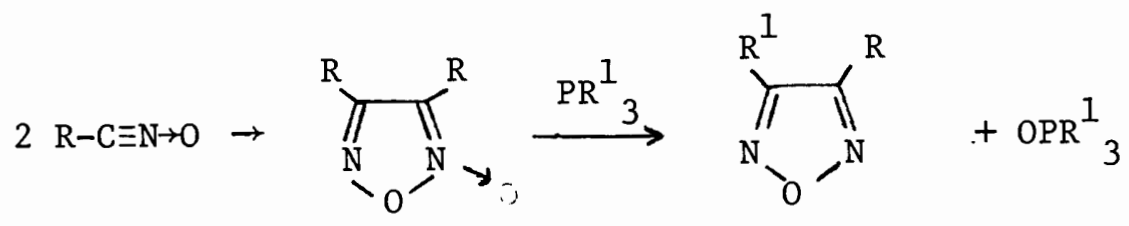

4. 1,2,4-oxadiazoles

$$
\mathrm{R}^{1}-\mathrm{C} \equiv \mathrm{N} \rightarrow \mathrm{O}+\sum_{\mathrm{R}^{4}}^{\mathrm{R}^{3}}=\mathrm{N}-\mathrm{R}^{2} \rightarrow \sum_{0}^{\mathrm{N}} X_{\mathrm{R}^{4}}^{\mathrm{R}^{1}}
$$


51

5.

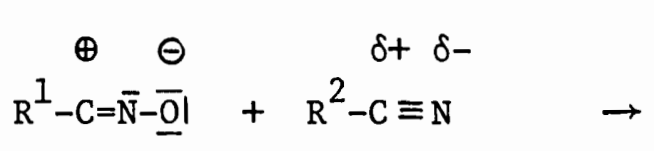

6. $1,2,3,5$-oxatriazoles

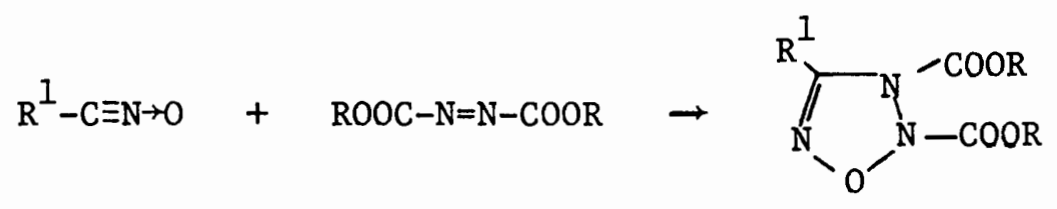

7.

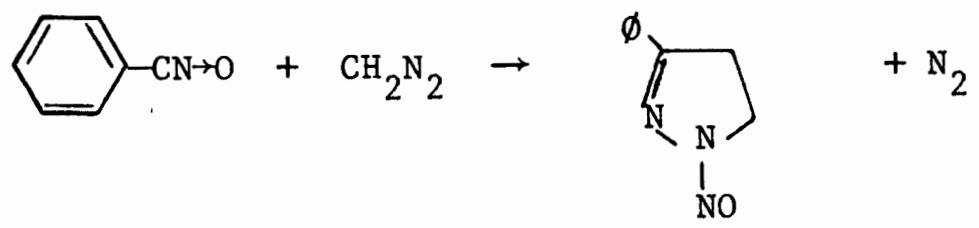




\section{APPENDIX B}

REACTIONS OF NITRILE OXIDES WITH NUCLEOPHILES

The following are some examples illustrating reactions of nitrile oxides with nucleophiles yielding open chain 1,3-addition products.

1. $\underline{\mathrm{H}}$<smiles>COc1ccc2c(c1)C1(C)CCCC(C)(C#N)C1CC2</smiles><smiles>COc1ccc2c(c1)C1(C)CCCC(C)(/C=N/O)C1CC2</smiles>

(syn)

2. $\mathrm{H}_{2} \mathrm{O}$

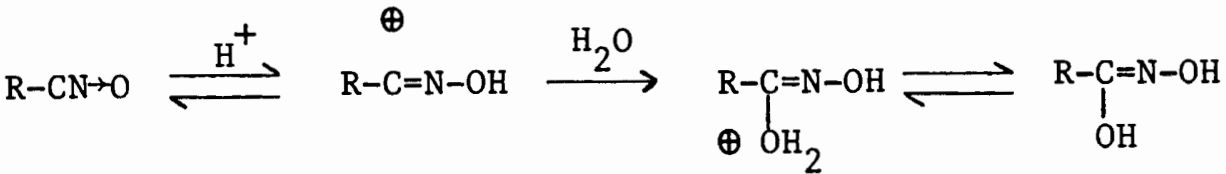

3. $\mathrm{ROH}$ or $\mathrm{ArOH}$

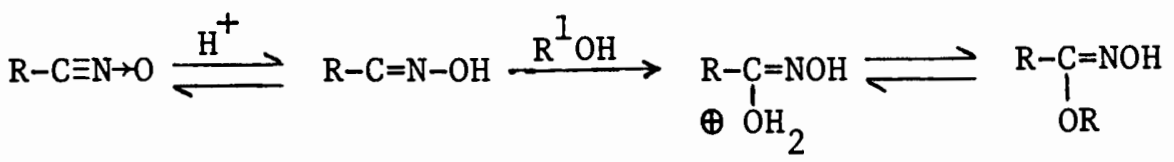

4. $\mathrm{NH}_{3}$

$\mathrm{R}-\mathrm{C} \equiv \mathrm{N} \rightarrow \mathrm{O}+\prod_{\mathrm{NOH}}^{\mathrm{NH}}$ 
Appendix B (cont.)

$$
\begin{aligned}
& \mathrm{NH}_{2} \mathrm{NH}_{2}
\end{aligned}
$$

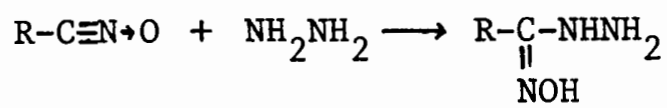

$$
\begin{aligned}
& \underline{\mathrm{NH}_{2} \mathrm{OH}}
\end{aligned}
$$

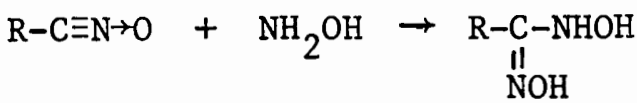

5.

$$
\mathrm{R}-\mathrm{C} \equiv \mathrm{N} \rightarrow \mathrm{O}+\mathrm{H}-\mathrm{N}_{\mathrm{R}^{2}} \mathrm{R}^{1} \rightarrow \prod_{\mathrm{NOH}}^{\mathrm{R}-\mathrm{C}-\mathrm{N}^{2}} \mathrm{R}^{1}
$$

6. Free radicals

$$
\mathrm{Ar}-\mathrm{C} \equiv \mathrm{N} \rightarrow \mathrm{O}+\mathrm{R} \cdot \underset{\mathrm{R}}{\mathrm{Ar}-\mathrm{C}=\mathrm{N}-\mathrm{O}} \stackrel{\mathrm{H}_{2} \mathrm{O}}{\longrightarrow} \underset{\mathrm{R}}{\mathrm{Ar}-\mathrm{C}=\mathrm{N}-\mathrm{OH}}
$$

\section{Alkyl chlorides}

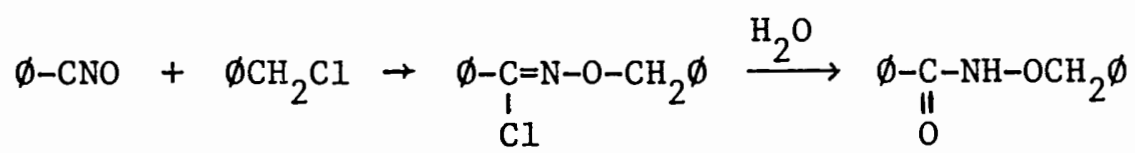


Appendix B (cont.)

8. Nitrenes and carbenes

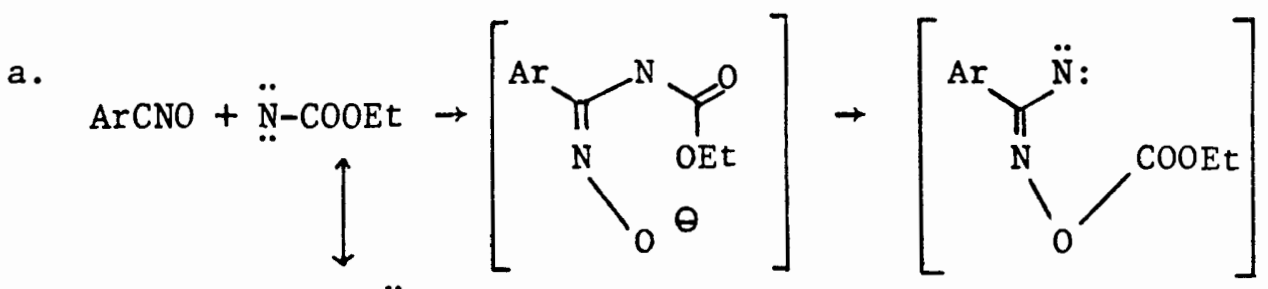

$\oplus_{\mathrm{N}=\mathrm{C}-\ddot{\mathrm{O}}:} \theta$

$O E$

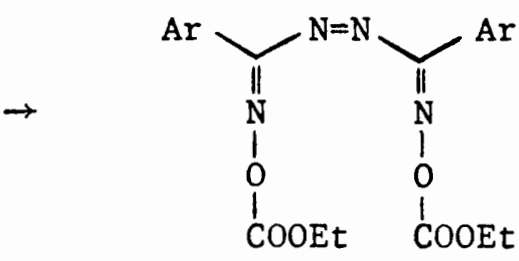

b. $\emptyset-\mathrm{C} \equiv \mathrm{N} \rightarrow \mathrm{O}$

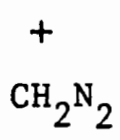

$[\overbrace{\substack{\mathrm{N} \\ \mathrm{N}}}^{\emptyset \mathrm{N}}$<smiles>CC</smiles><smiles>CC1=N[Al]([O-])CCC(C)C1</smiles><smiles>CCCCC(O)=NO[O-]</smiles><smiles>CCCCC(O)=[Nb]=O</smiles><smiles>CN1C(=O)CCN1[N+](=O)[O-]</smiles><smiles>OC1=NOCC1</smiles> 
APPENDIX C

\section{ઈ-LACTAM PREPARATIONS}

The following are some examples of current $\delta$-lactam preparations.

1. Photolysis

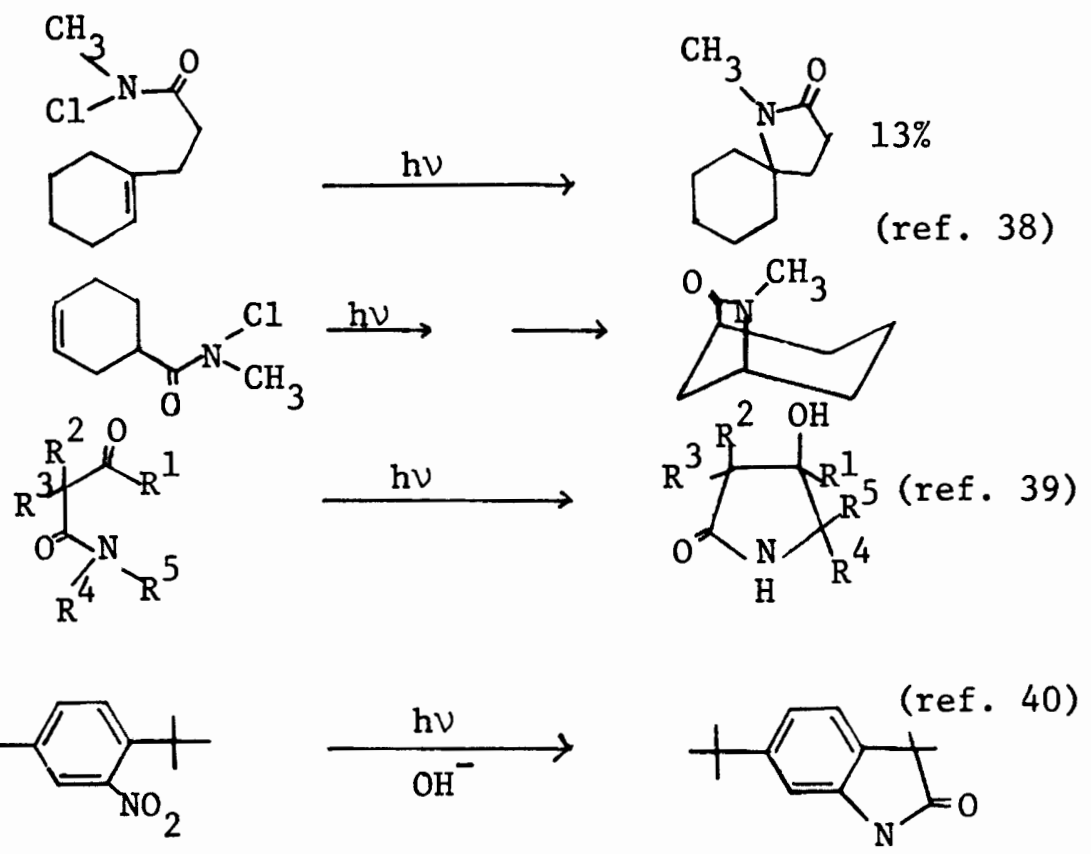

2. Acidic conditions
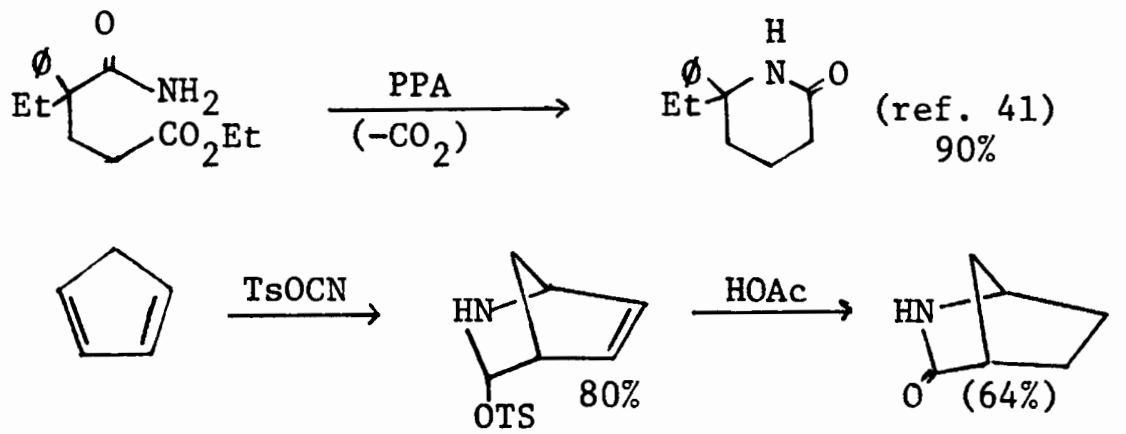

(ref. 42) 
Appendix C (cont.)

3. Cyclizing agents<smiles>[R]C/C=C\C(N)=O</smiles>

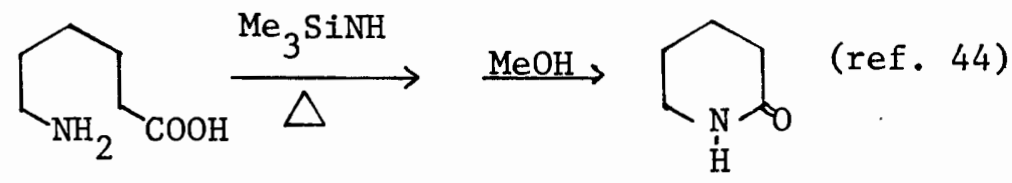

